\title{
2. SITE 303: JAPANESE MAGNETIC LINEATIONS
}

\author{
The Shipboard Scientific Party ${ }^{1}$
}

\section{SITE DATA}

Date Occupied: 18 August 1973 (2351)

Date Departed: 24 August 1973 (0800)

Time on Site: 128 hours

Position: $40^{\circ} 48.50^{\prime} \mathrm{N}, 154^{\circ} 27.07^{\prime} \mathrm{E}$

Water Depth: 5609 corrected meters (echo sounding)

Bottom Felt With Drill Pipe At: 5625 meters below rig floor Penetration: 293 meters

Number of Holes: 2

Number of Cores: 16

Total Length of Cored Section: 136.0 meters

Total Core Recovered: 31.7 meters

\section{BACKGROUND AND OBJECTIVES}

The evolution of the northwestern Pacific Ocean has been modeled by Larson and Chase (1972), based on correlations of three sets of linear magnetic anomalies and consideration of their geometry. These anomalies have been numbered M-1 (youngest) through M-22. An east-striking set near the Phoenix Islands was drilled on Leg 17, where the lowest sediment over basalt was Hauterivian in age between $M-7$ and $M-8$. In the western North Atlantic, the north-striking Keathley linear anomalies have been correlated with $\mathbf{M}-2$ through M-22, and Oxfordian-Callovian(?) sediments cored on Leg 11 lie on basalt immediately west of M-22.

Site 303 (Figure 1) lies on the Japanese lineation pattern, an east-striking set of anomalies (M-4 to M-10, also possibly $\mathrm{M}-11$ and $\mathrm{M}-12$ ) that are located east of the Japanese Islands. Site 303 is located on anomaly M4 , the northernmost of these extremely linear features. The main goal at Site 303 is to drill to basement and determine its age, either from the overlying sediments or radiometric dating of the basalt itself. This will establish or deny the contention of Larson and Chase (1972) that the Japanese lineations correlate with the Phoenix lineations as features that result from sea-floor spreading and

'Roger L. Larson, Lamont-Doherty Geological Observatory, Palisades, New York (Co-chief scientist); Ralph Moberly, Hawaii Institute of Geophysics, Honolulu, Hawaii (Co-chief scientist); David Bukry, U.S. Geological Survey, La Jolla, California; Helen P. Foreman, Oberlin College, Oberlin, Ohio; James V. Gardner, Scripps Institution of Oceanography, La Jolla, California; John B. Keene, Scripps Institution of Oceanography, La Jolla, California; Yves Lancelot, Lamont-Doherty Geological Observatory, Palisades, New York; Hanspeter Luterbacher, Esso Production Research-European, Begles, France; Monte C. Marshall, U. S. Geological Survey, Menlo Park, California; Albert Matter, Universitat Bern, Bern, Switzerland.

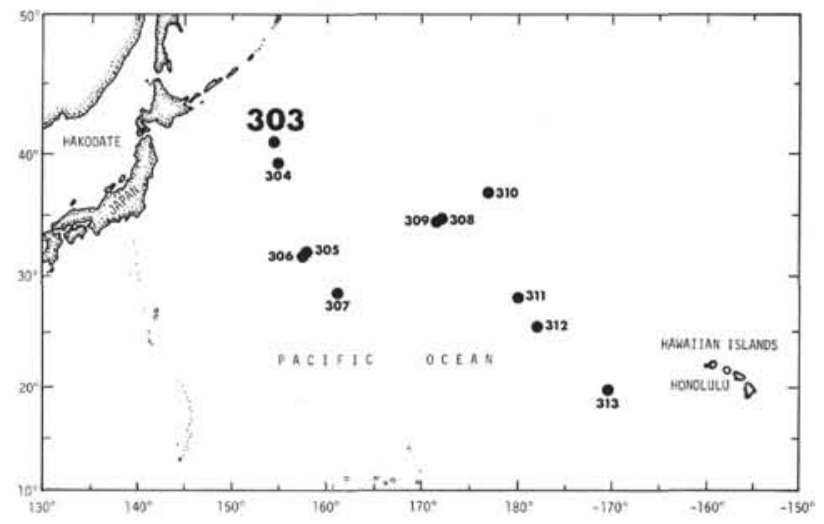

magnetic field reversals during the Early Cretaceous. Site 303 will also test and further calibrate the late Mesozoic reversal time scale of Larson and Pitman (1972) that predicts a Barremian or possibly Hauterivian age for anomaly $\mathrm{M}-4$.

Besides the intrinsic interest of correlating the anomaly sets and establishing a well-founded time scale for Mesozoic magnetic field reversals, this study will also test the hypothesis of Larson and Pitman (1972) that the Late Cretaceous period between the "Cenozoic" and Mesozoic reversals was the time of a worldwide increase in sea-floor-spreading rates. Larson and Pitman have related this spreading "pulse" to a simultaneous pulse in batholith emplacement around the Pacific Basin and Hays and Pitman (1973) have postulated the spreading pulse as the cause of the worldwide transgression of epicontinental seas during the Late Cretaceous. Because M-4 lies close to the top of the late Mesozoic reversal sequence, its basement age will have a significant bearing on the reality of this hypothesis of increased spreading rates during the Late Cretaceous.

The sediments at Site 303 should contain carbonate material that is a record of the early deposition on the newly formed crust and also a record of the equatorial crossing of this part of the Pacific plate, as it is proposed that this site was formed very close to, or at the equator. Determination of the age and nature of these "ridge crest" and "equatorial" carbonate sequences should add considerable information to the evolution of this area since its formation.

It may also be possible to compare cherts at Site 303 with those of the same age recovered from shallowwater sites, with an attempt to sort out other factors in chertification, such as percentage of carbonate, etc. Diagenetic studies of zeolitic, pelagic clays will also be undertaken. 


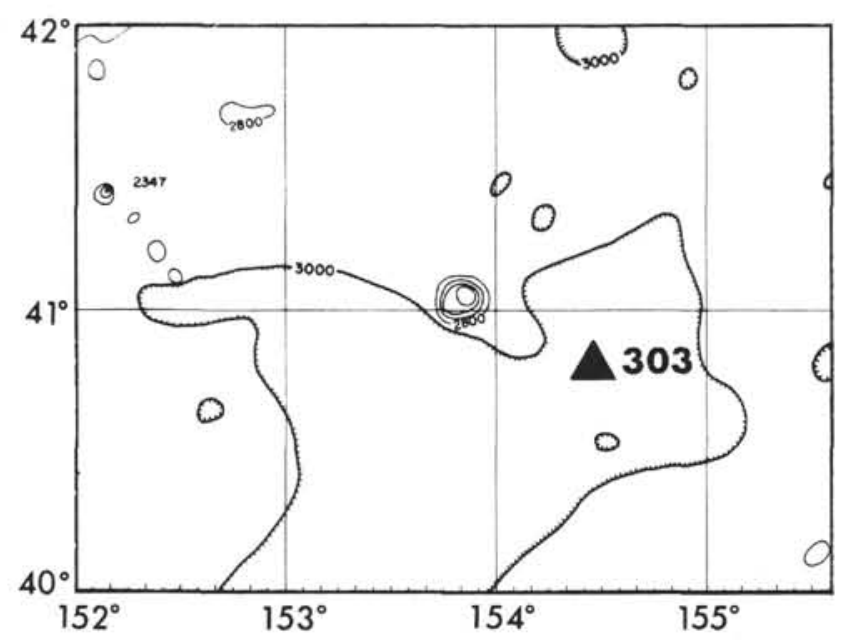

Figure 1. Bathymetry in the region of Site 303 (after Chase et al., 1971). Contour interval $200 \mathrm{fm}$ uncorrected.

At Site 303 the anticipated basement is ridge-cresttype tholeiite (commonly olivine-normative and very low in alkalies) with pillows and hyaloclastites which typify many previous DSDP basaltic sites. However, these rocks will be older than those previously encountered, and by projection of the physical measurements of Christensen (Salisbury and Christensen, 1972) and the mineralogical determinations of Bass (Bass et al., 1973) on marine basalts of various ages, these should be severely altered. Their study will provide an end member to the spectrum of basalt alteration and will be useful to geophysicists in refraction seismology, to geochemists postulating the composition of subducted crust, and perhaps to geochemists interested in the transfer of transition elements from volcanic rocks to overlying sediments.

The magnetic properties of the basement rocks that are presumably oceanic tholeiite should be of considerable interest. We are especially concerned with the remnant magnetic inclination, which should be low or nearly horizontal if the rocks were emplaced and thus magnetized at the equator. Recent studies by Lowrie et al. (1973) have demonstrated a marginal correspondence between measured inclinations and values that were predicted from tectonic reconstruction and/or skewnesses of the marine magnetic anomalies. We are also interested in the magnetic mineral content of the basalts and the stability and intensity of remnant magnetization.

\section{OPERATIONS}

With the intention of holding our survey time to a minimum, we intersected the Conrad-1405 track, our reference profile, immediately north of the intended site (Figure 2). After turning to run parallel with the Conrad track, we slowed in order to retrieve one of the hydrophone streamers and maintained 5 knots until the profiles of the magnetometer and airgun showed a suitable site on magnetic anomaly $\mathrm{M}-4$. The seismic profile (Figure 3) suggested the section above the deepest reflector would be about 30 meters thinner than the section shown on the Conrad profile, but otherwise it was

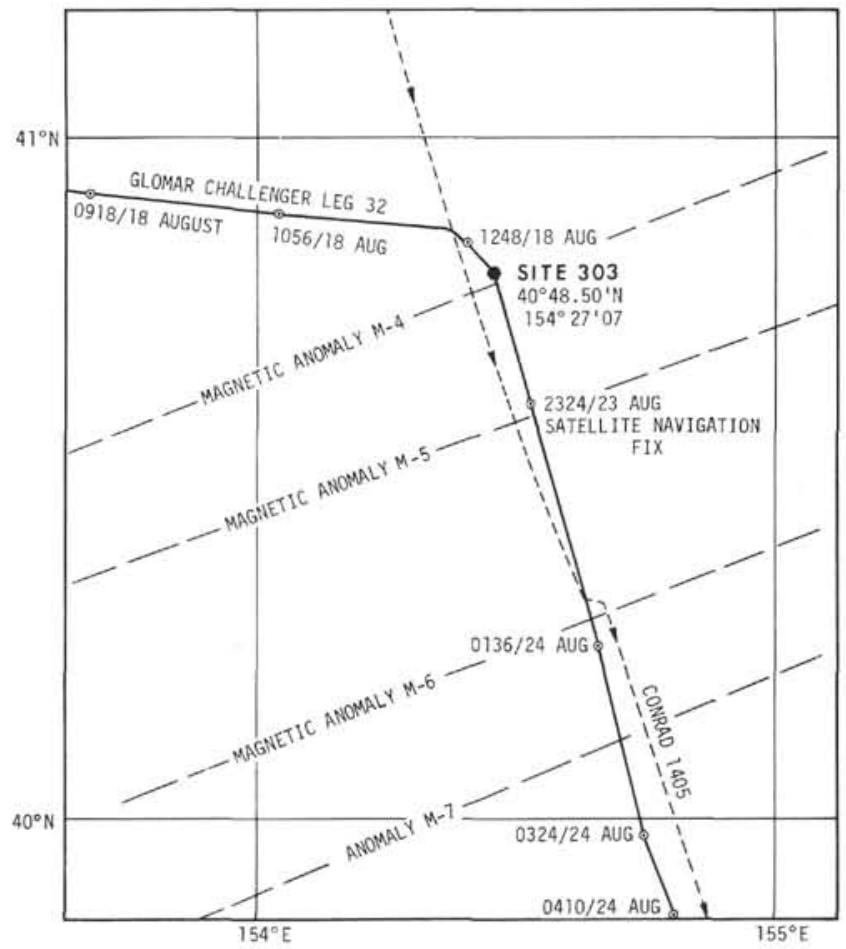

Figure 2. Track chart in the vicinity of Site 303. Solid track is Leg 32 Glomar Challenger, short dashed track is from Conrad 1405, and long dashed lines mark identified magnetic anomalies. Navigation points marked with open circles and annotated time/day-month.

comparable. No beacon had been presoaked to be dropped "on the run," so a lighted spar buoy was jettisoned to mark the site while the ship was turned about and the remaining geophysical gear was retrieved. An acoustic beacon was dropped at 2351, 18 August 1973 in a water depth of 5609 meters (corrected by Matthews' Tables from the echo sounder).

A seismic record from a sonobuoy was attempted on station, but it was terminated early when a momentary loss of propulsion allowed the ship to be blown back over the buoyed airguns, with potential damage to the packings of the propeller shafts. The direct water wave had become impossible to detect in the propeller and thruster noise by that time anyway, and so the principal value of the sonobuoy record was to be its indication of no strong reflectors in the upper part of the section. We were thereby assured that the drill collars could be buried to support them laterally before any hard drilling commenced.

An excursion northward to stream geophysical gear, and then a turn to cross over the beacon on course to Site 304 sufficed for a postsite survey (Figure 2).

Nearly $35 \mathrm{hr}$ elapsed between the initial occupation of Site 303 and the initial recovery of sediment. The part due to the depth of water had been expected. A weather front with winds gusting above 40 knots while rapidly shifting direction was compounded with the site's location in the Kuroshio Extension Current, and the re- 


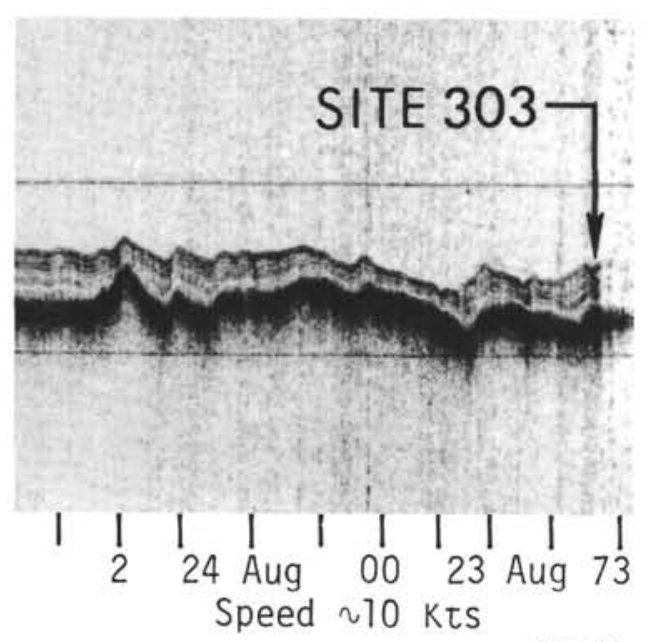

$165^{\circ}$

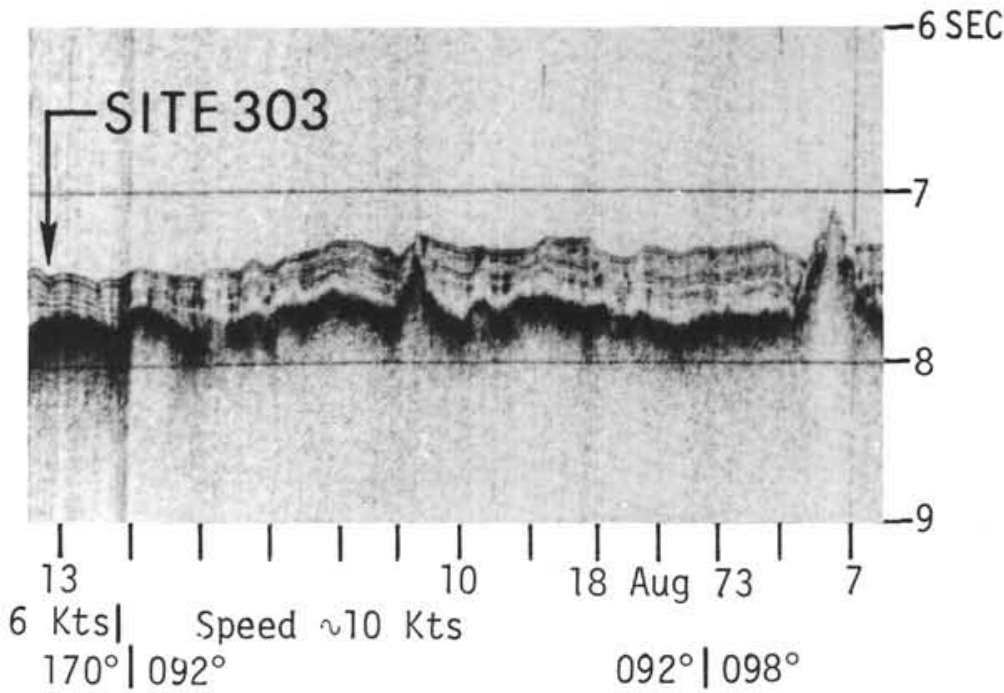

Figure 3. Seismic profiler section approaching and leaving Site 303.

sulting positioning problems caused a few hours of delay. The first beacon had a very weak signal and had to be replaced with a second beacon after $12 \mathrm{hr}$. Several stands of old drill pipe had been replaced by new pipe, but the new pipe was not exactly the same length as the old lengths and had not been measured. Two coring trips that turned out to be in the water over the bottom, and additional time for speculation, were expended while attempting to find the sea floor with the drill string, due to the unknown length of the drill string and the absence onboard of any in-pipe or expendable pinger.

Between the surface and 211 meters we cored at intervals of approximately 50 meters, with little or no rotation or circulation, and generally good recovery. Below 211 meters we intended to core continuously. While retrieving Core 5 , the inner barrel jammed at 500 meters above the bit and the safety pin in the overshot latch sheared while attempting to pull it free. The barrel was pumped down with mud, the overshot latched on, and the barrel pulled slowly to the surface. However, Core 6 jammed solidly in the lowermost drill collar, and after breaking two more safety pins and running a magnet down the pipe, the drill string had to be pulled out of the hole to clean the obstruction. A piece of a steel snaphook that had fallen into the drill pipe had wedged the barrel firmly.

The absence of chert in the moderately thick Miocene siliceous ooze intensified our belief that this site afforded an excellent opportunity to reach basement in this part of the northwestern Pacific, and so we continued by drilling Hole 303A. The upper section was washed and drilled to 211 meters, and we again commenced a program of coring continuously. Recovery in the interbedded chert and zeolitic mud was poor, however, and on two occasions slugs of mud were pumped in attempts to lift the abundant chert cuttings and chips out of the hole. Basalt was encountered in
Core 9A. We had planned next to take a full 9-meter core of basalt, followed by a partial core, using the Sperry-Sun orienting device. However, only 5 meters of Core 10A had been penetrated when the bit stuck, presumably from chert chips that continued to cave into the hole, and that core was pulled as soon as the bit could be freed. There was, therefore, no attempt to cut an oriented core, as the orientation process requires intervals when circulation and rotation must be stopped.

Fossiliferous sediment had been recovered within a meter or two of extrusive basement, and so although the time on station was lengthy and we were plagued with minor operational difficulties in addition to those listed above, our primary objective of dating magnetic anomaly M-4 was fulfilled. The site was abandoned after Core $10 \mathrm{~A}$ at a total depth of 293 meters. We were underway at 0800, 24 August 1973).

The intervals drilled and cored in Holes 303 and 303A are listed in Table 1.

\section{LITHOLOGIC SUMMARY}

Most of the section present at Site 303 has been sampled in two consecutive holes. The section sampled can be considered as a single record of the sediment present at the site because coring in Hole 303A overlapped the lowermost level reached in Hole 303. Coring was terminated in basaltic rocks at the bottom of Hole 303A. Table 2 shows a summary of the smear slide data.

The upper part of the section was sampled discontinuously from 0 to 211 meters subbottom and continuously from 211 meters to the bottom of Hole 303A $(293 \mathrm{~m})$. Recovery was relatively good in the upper 183 meters and very poor in the lower part due to the occurrence of abundant interbedded chert.

The section can be divided into four units as follows:

Unit 1-Diatom-rich radiolarian ooze, commonly rich in volcanic ash and grading down to radiolarianbearing pelagic clay (Cores 1 through 4 ). 
TABLE 1

Coring Summary

\begin{tabular}{|c|c|c|c|c|c|c|c|}
\hline Core & $\begin{array}{l}\text { Date } \\
\text { (Aug. } \\
\text { 1973) }\end{array}$ & Time & $\begin{array}{l}\text { Depth From } \\
\text { Drill Floor } \\
(\mathrm{m})\end{array}$ & $\begin{array}{l}\text { Depth Below } \\
\text { Sea Floor } \\
(\mathrm{m})\end{array}$ & $\begin{array}{l}\text { Length } \\
\text { Cored } \\
\text { (m) }\end{array}$ & $\begin{array}{l}\text { Length } \\
\text { Recovered } \\
\text { (m) }\end{array}$ & $\begin{array}{c}\text { Recovery } \\
(\%)\end{array}$ \\
\hline \multicolumn{8}{|c|}{ Hole 303} \\
\hline $\begin{array}{l}1 \\
2 \\
3 \\
4 \\
5 \\
6\end{array}$ & $\begin{array}{l}20 \\
20 \\
20 \\
20 \\
21 \\
22\end{array}$ & $\begin{array}{l}1000 \\
1330 \\
1550 \\
1845 \\
0430 \\
0015\end{array}$ & $\begin{array}{l}5625.0-5637.0 \\
5687.0-5696.0 \\
5742.0-5751.0 \\
5799.0-5808.0 \\
5836.0-5845.0 \\
5845.0-5854.0\end{array}$ & $\begin{array}{c}0.0-12.0 \\
62.0-71.0 \\
117.0-126.0 \\
174.0-183.0 \\
211.0-220.0 \\
220.0-229.0\end{array}$ & $\begin{array}{l}9.0 \\
9.0 \\
9.0 \\
9.0 \\
9.0 \\
9.0 \\
\end{array}$ & $\begin{array}{l}0.5 \\
9.0 \\
8.0 \\
8.3 \\
\text { tr } \\
0.0 \\
\end{array}$ & $\begin{array}{r}5 \\
100 \\
89 \\
92 \\
<1 \\
0 \\
\end{array}$ \\
\hline Total & & & & & 54.0 & 25.8 & 47.8 \\
\hline \multicolumn{8}{|c|}{ Hole $303 \mathrm{~A}$} \\
\hline $\begin{array}{r}1 \\
2 \\
3 \\
4 \\
5 \\
6 \\
7 \\
8 \\
9 \\
10\end{array}$ & $\begin{array}{l}22 \\
22 \\
22 \\
22 \\
23 \\
23 \\
23 \\
23 \\
23 \\
23\end{array}$ & $\begin{array}{l}1725 \\
1920 \\
2120 \\
2325 \\
0255 \\
0510 \\
0720 \\
0930 \\
1200 \\
1640\end{array}$ & $\begin{array}{l}5836.00-5845.00 \\
5845.00-5854.25 \\
5854.25-5863.50 \\
5863.50-5872.75 \\
5872.75-5882.00 \\
5882.00-5891.25 \\
5891.25-5900.50 \\
5900.50-5909.75 \\
5909.75-5913.00 \\
5913.00-5918.00\end{array}$ & $\begin{array}{l}211.00-220.00 \\
220.00-229.25 \\
229.25-238.50 \\
238.50-247.75 \\
247.75-257.00 \\
257.00-266.25 \\
266.25-275.50 \\
275.50-284.75 \\
284.75-288.00 \\
288.00-293.00\end{array}$ & $\begin{array}{l}9.00 \\
9.25 \\
9.25 \\
9.25 \\
9.25 \\
9.25 \\
9.25 \\
9.25 \\
3.25 \\
5.00 \\
\end{array}$ & $\begin{array}{l}\operatorname{tr} \\
\operatorname{tr} \\
0.2 \\
0.4 \\
1.5 \\
0.4 \\
0.5 \\
0.4 \\
1.5 \\
1.0 \\
\end{array}$ & $\begin{array}{r}<1 \\
<1 \\
2 \\
4 \\
4 \\
16 \\
4 \\
5 \\
4 \\
46 \\
20 \\
\end{array}$ \\
\hline Total & & & & & 82.00 & 5.9 & 7.3 \\
\hline Site $T$ & & & & & 136.0 & 31.7 & 23.3 \\
\hline
\end{tabular}

Unit 2-Zeolitic pelagic clay and chert (Core 5 and Cores $1 \mathrm{~A}$ through $5 \mathrm{~A}$ ). $8 \mathrm{~A})$.

Unit 3-Clayey nanno ooze and chert (Cores 7A and

Unit 4-Basalt (Cores 9A and 10A).

Unit 1-Diatom-radiolarian Ooze and

Radiolarian-bearing Pelagic Clay (Cores 1 through 4)

The upper part of this unit (Core 1) consists of wellpreserved siliceous fossil remains and volcanic glass shards in roughly equal amounts. The siliceous microfossils are predominantly diatoms, generally very well preserved, with lesser amounts of radiolarians and silicoflagellates.

The volcanic components are predominantly lightcolored glass shards with rare colored glass and occasional feldspar fragments.

Some small angular quartz grains (possibly wind transported) are also found in smear slides from the first two cores. X-ray diffraction analysis (Zemmels, Johnson, and Cook, this volume) shows relatively abundant quartz throughout this interval. Below Core 1 the sediment composition shows a very noticeable decrease in the amount of volcanogenic components except in thin layers and mottles. The sediment consists predominantly of diatoms and radiolarians in nearly equal amounts, with some silicoflagellates and minor amounts of lightcolored volcanic glass shards. Clay minerals are generally absent in the smear slides except in a small green hard nodule in Core 2, Section 1. However, relatively abundant mica and montmorillonite are reported in the Xray analysis results. The occurrence of both these minerals in roughly comparable amounts suggests a duality in the sources. The relatively abundant quartz and mica indicate significant terrigenous contribution to the sediment.

Core 4 shows a gradual transition between this unit and the underlying one. It consists of zeolitic pelagic clay with upward increasing amounts of radiolarians and diatoms. The radiolarian fragments show evidence of dissolution yet some diatom fragments appear to remain well preserved.

\section{Unit 2-Zeolitic Pelagic Clay and Chert (Core 5 and Cores $1 \mathrm{~A}$ through $\mathbf{5 A}$ )}

Core 5 recovered only a smear of slightly zeolitic brown pelagic clay with small angular chert fragments. The top of the chert-bearing section is not precisely known and might be between Cores 4 and 5 . The dissolution of radiolarian fragments at the base of Core 4 suggests that the youngest chert in the section might lie rather close to the base of Unit 1 although the drilling record shows that the first hard layer was encountered at 217 meters while cutting Core 5 .

The relative amounts of chert and clay in this unit are unknown due to the poor recovery in this kind of sediment. The clay is generally very zeolitic, especially in some light-colored layers where zeolites and clay minerals appear to occur in equal amounts. The zeolites are predominantly clinoptilolite with rare occurrences of phillipsite. Amorphous iron oxide, finely dispersed or concentrated in microscopic aggregates or in micronodules, is present throughout but hematite is very rare. Volcanic glass is present in minor amounts.

Radiolarian remains are common; they are generally chalcedony-filled molds similar to those observed in the chert. 
TABLE 2

Smear Slide Summary, Holes 303, 303A

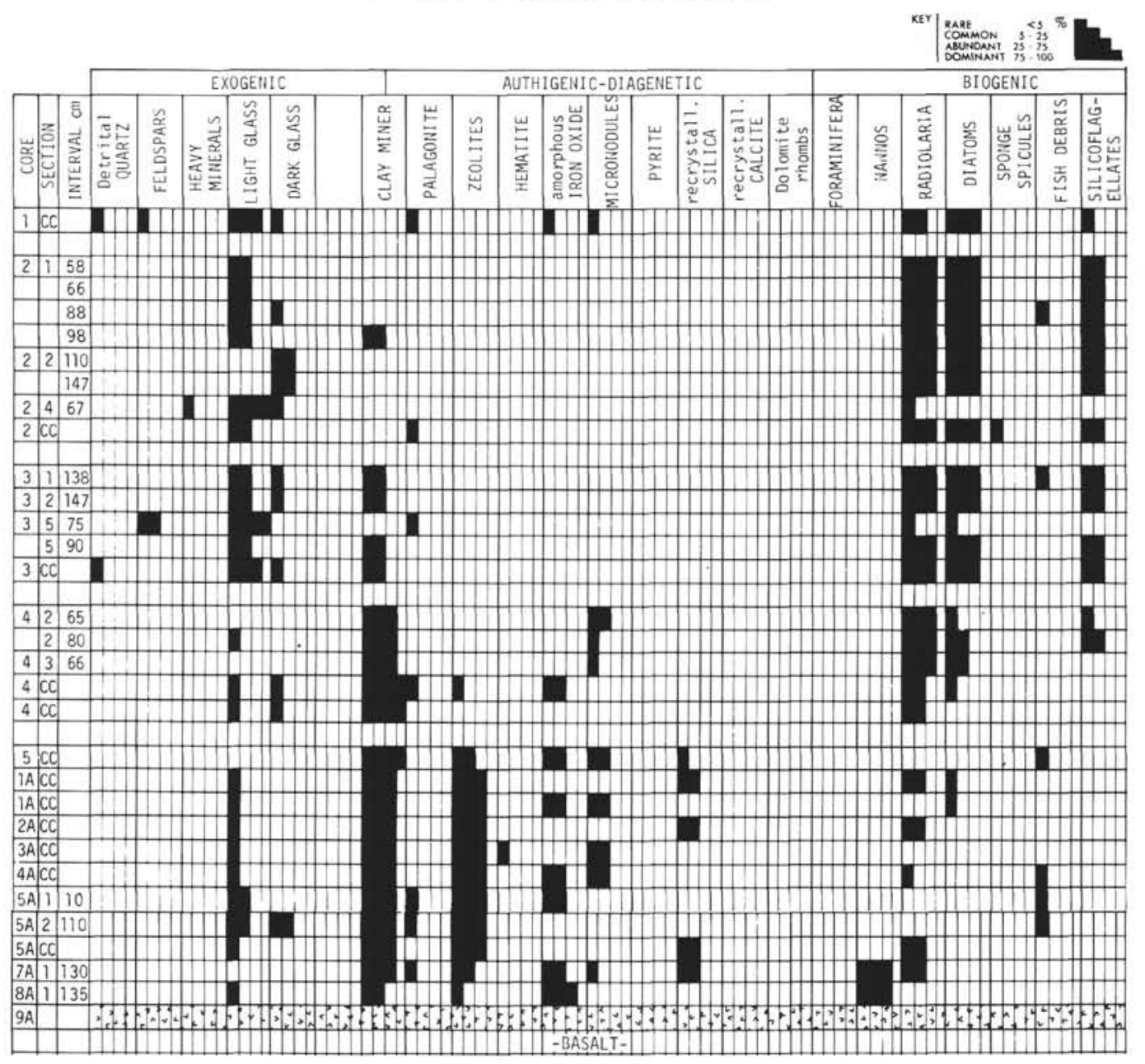


Chert nodules (or possibly layers) are dark brown to yellowish-brown and display well-preserved sedimentary structures such as discrete layering and microfaulting. They contain inclusions of partially silicified sediment. Abundant radiolarian molds filled with chalcedony are also found in the cherts. The chert at 252 meters was the layer most resistant to drilling for the entire site.

\section{Unit 3-Clayey Nanno Ooze and Chert (Cores $7 \mathrm{~A}$ and $\mathbf{8 A}$ )}

Although coring was continuous, poor recovery caused by the combined occurrence of chert and soft sediments precludes any precise estimate of the actual composition of this section. Only very disturbed and small sections were recovered which contain abundant chert fragments and watery sediment. Part of the chert fragments may have fallen from upper parts of the hole, but some of them are clearly associated with the nannofossil ooze since they contain some carbonate inclusions.

The sediment consists of clayey nanno ooze but it is not clear whether the occurrence of clay is due to thorough mixing during recovery or it corresponds to the actual composition of the sediments.

Nannofossils are abundant to dominant and the rest of the sediment consists of clay minerals, zeolites, glass shards, chert fragments, and amorphous iron oxide, as in the unit above.

The base of this unit lies at the contact with extrusive basalt. This contact was not actually sampled although Core $8 \mathrm{~A}$ bottomed no more than 2 meters above basement and is probably within 1 meter of the contact. It is probable that the soft calcareous sediments overlying the basalt were washed away during the cutting of Core 9 A.

\section{Unit 4-Fine-grained, Extrusive Basalt (Cores $9 \mathrm{~A}$ and 10A)}

This unit consists of fine- to very fine-grained basalt. Although no glassy selvage survived drilling, the presence of varioles $22 \mathrm{~cm}$ below the top of the basalt as well as alternating darker, more finely crystalline, and lighter, less finely crystalline, intervals show the basalt consists of several cooling units and is most likely an extrusive, pillow basalt. The contact between the basalt and the overlying sediment was not recovered. The basalt is highly fractured, the average fracture spacing being about $2-3 \mathrm{~cm}$. The fractures are filled with calcite and a green ( xccasionally red) clayey material (celadonite and montmorillonite). The deepest piece recovered is a 4-cm-diameter, rounded piece of limestone, well abraded from coring. It may be sediment that was squeezed between, or was deposited between, pillows.

In thin section, the basalt is seen to consist of plagioclase laths with interstitial pyroxene, magnetite, ilmenite, and patches of green-orange alteration (celadonite and montmorillonite, the color depending on the amount of admixed goethite [?]). The irregular patches are possibly altered interstitial glass, while the more "euhedral" ones are altered olivine (?) phenocrysts. A point count ( $200 \mathrm{pts})$ gives the following mode: plagioclase $54 \%$, pyroxene $34 \%$, magnetite and ilmenite $7 \%$, alteration 5\%. The plagioclase laths and pyroxene grains appear to be largely unaltered, which is remarkable considering the age of this basalt.

The degree of weathering of the basalt is not uniform throughout the section. In several of the core segments the basalt adjacent to fractures is green, whereas the basalt $1-2 \mathrm{~cm}$ distant is gray and apparently unaltered.

\section{Conclusions}

Most of the section consists of sediments deposited below the carbonate compensation depth except for the lowermost layers recovered immediately above basement. The relatively high rates of sedimentation observed in the upper part (see below, Sedimentation Rates) probably result from a combination of high productivity related to the Kuroshio-Oyashio current system as well as contributions from volcanogenic components.

A major unsampled hiatus is probably present at the base of the Tertiary and top of the Cretaceous, and the upper Mesozoic section appears to be very thin. This interval was probably deposited in areas of rather low productivity north of the equatorial zone. The carbonate-rich layers recovered at the base of the section appear too thin to account for accumulation of "ridge flank" and "equatorial" types of sedimentation. This suggests that the crust at this site was not generated under the equatorial zone of high productivity.

It is probable that the crust was generated south of the equator and that the equatorial crossing is recorded by large amounts of siliceous deposits after the area had subsided beneath the carbonate compensation depth (CCD) (see discussion in Lancelot and Larson, this volume).

\section{GEOCHEMICAL MEASUREMENTS}

Alkalinity, $p \mathrm{H}$, and salinity measurements are summarized in Table 3 and presented graphically in Figure 4 . The core samples were squeezed at $4^{\circ} \mathrm{C}$ to obtain the interstitial water. Techniques used were those routinely performed during previous legs and are described in the following pages.

\section{Alkalinity}

Surface seawater and three cored samples were analyzed. More samples could not be taken because of drilling disturbance in the sediment. The maximum alkalinity of $4.83 \mathrm{meq} / \mathrm{kg}$ was obtained from Unit 1 at 124.5 meters subbottom. This unit is a diatom-radiolarian ooze. The lowest value for the interstitial water was $2.85 \mathrm{meq} / \mathrm{kg}$ from the deepest sample $(181.5 \mathrm{~m})$ in a radiolarian-bearing clay of Unit 1 . The surface water alkalinity was 2.43 . The values obtained in these samples are reasonable for this type of sediment.

\section{pH}

The two $p \mathrm{H}$ values obtained by the punch-in method were both below that of seawater at the site, which is normal for marine sediments. The sample from Core 4 was too stiff to use the punch-in method. The increase in $p \mathrm{H}$ to 8.43 in Core 3 , using the combination electrode, seems high and is probably incorrect; however, there is 
TABLE 3

Summary of Shipboard Geochemical Data

\begin{tabular}{lcccccc}
\hline $\begin{array}{c}\text { Sample } \\
\text { (Interval } \\
\text { in cm) }\end{array}$ & $\begin{array}{c}\text { Depth Below } \\
\text { Sea Floor (m) }\end{array}$ & $\begin{array}{c}\text { Punch- } \\
\text { in }\end{array}$ & $\begin{array}{c}\text { Flow- } \\
\text { through }\end{array}$ & $\begin{array}{c}\text { Alkalinity } \\
(\mathrm{meq} / \mathrm{kg})\end{array}$ & $\begin{array}{c}\text { Salinity } \\
(\%)\end{array}$ & $\begin{array}{c}\text { Remarks } \\
(\text { Combination } \\
\text { electrode } p \mathrm{H})\end{array}$ \\
\hline Surface Seawater & & 8.19 & - & 2.43 & 34.6 & 8.29 \\
$2-5,144-150$ & $52-71$ & 7.53 & - & 4.67 & 35.2 & 7.96 \\
$3-5,144-150$ & $117-126$ & 7.18 & - & 4.83 & 35.2 & 8.43 \\
$4-5,144-150$ & $174-183$ & - & - & 2.85 & 35.2 & 7.44 \\
\hline
\end{tabular}
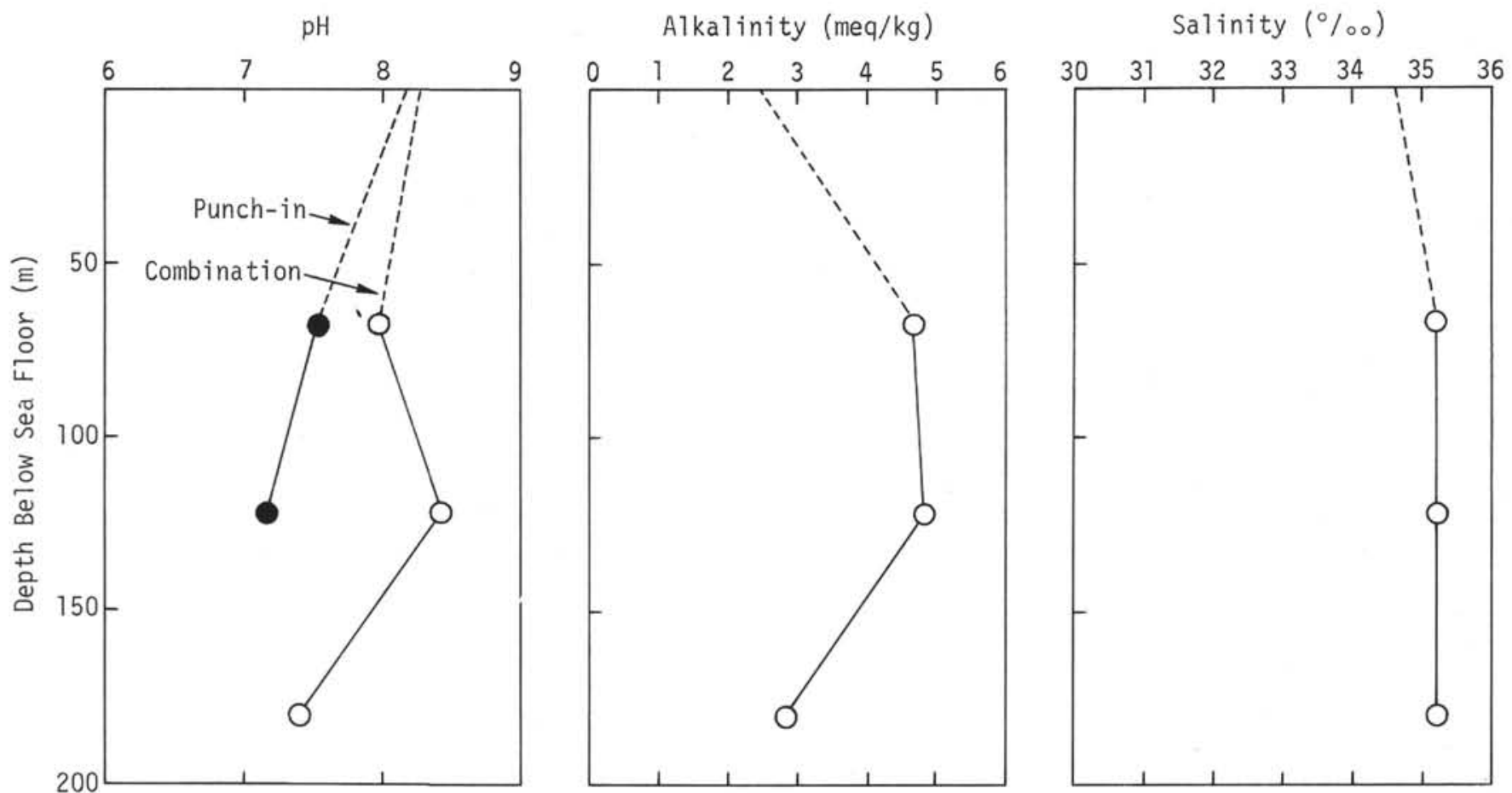

Figure 4. Graphic summary of geochemical data taken at Site 303.

no obvious explanation for this result. The equipment for the flow-through method was broken during the site analyses.

\section{Salinity}

The three salinity measurements made were all similar to the surface seawater value.

\section{PHYSICAL PROPERTIES}

\section{Wet Bulk Density and Porosity of Soft Sediments}

The wet bulk density of most of the soft to stiff and moderately to intensely disturbed sediments recovered from Hole 303 was measured continuously using the gamma-ray attenuation porosity evaluator (GRAPE). These data are summarized in Figure 6. The density is constant through most of each cored interval and increases from about $1.25 \mathrm{~g} / \mathrm{cc}$ in the radiolarian diatom ooze of Core 2 to $1.33 \mathrm{~g} / \mathrm{cc}$ in the clayey ooze and radiolarian-bearing pelagic clay of Cores 3 and 4 . A syringe sample was taken from each core as an independent measure of bulk density and porosity. The density of the clayey ooze and radiolarian-bearing pelagic clay, 1.36 $\mathrm{g} / \mathrm{cc}$, agrees with the GRAPE value, whereas the value measured in the ooze of Core $2,1.18 \mathrm{~g} / \mathrm{cc}$, is about $5 \%$ lower than the GRAPE value and suggests that the syringe sample is not entirely representative of the cored interval. The porosity, combining the GRAPE and syringe data, is about $85 \%$ in the radiolarian diatom ooze and $80 \%$ in the lower, clayey sediments.

\section{Velocity Measurements}

The compressional wave velocity, $V p$, of the soft sediments and rocks was measured with a Hamilton frame. $V p$ of the soft sediments was measured on the split cores, and that of the cherts and basalt was measured on fragments and small cores, respectively.

The $V p$ of the soft to stiff, moderately to intensely disturbed siliceous ooze and pelagic clay cluster closely around $1.50 \mathrm{~km} / \mathrm{sec}$. The $V p$ of the cherts is much higher and ranges from 3.7 to $5.2 \mathrm{~km} / \mathrm{sec}$. Some of the chert samples show a large anisotropy- $V p$ parallel to bedding is between 4 and $5 \mathrm{~km} / \mathrm{sec}$, whereas the velocity perpendicular to bedding is about $3.0 \mathrm{~km} / \mathrm{sec}$. This directional dependence results from the interlayering of 
earthy, relatively unsilicified (porcellanite) layers with much harder layers. Measured parallel to bedding, the first arrival of the sound wave is that transmitted by the well-indurated layers. Perpendicular to bedding, the sound velocity is an average of the soft, slow layers and the fast, hard layers. As expected, even the horizontal velocity of porcellanite samples containing no chert laminae is quite low (about $2 \mathrm{~km} / \mathrm{sec}$ ).

Since the $V p$ of well-silicified chert is considerably higher than that of unconsolidated sediments and porcellanites, such a chert layer should return much of the incident energy from the ship's sonic profiler. This explains why, upon drilling, the deepest reflector ("basement") shown on the profiler coincided with the most massive chert zone and not with the underlying basalt.

The $V p$ of the basalt samples group around 4.5 $\mathrm{km} / \mathrm{sec}$. This velocity is probably a maximum for the pillow basalt layer, since the somewhat rubbly contacts between pillows as well as the poorly cemented fractures reduce the average velocity.

\section{CORRELATION OF SEISMIC REFLECTION PROFILES WITH DRILLING RESULTS}

The seismic reflection profiles recorded while approaching and leaving (Figure 3 ) Site 303 show a faintly stratified layer, approximately $0.31 \mathrm{sec}$ thick, overlying a highly reflective acoustic basement. Examination of profiles in the area suggests that this acoustic basement is probably composed of two reflective layers too closely spaced to be separated on the record at Site 303. A transparent interval can indeed be observed at and south of Site 304. It becomes undiscernible around Site 304 and disappears gradually toward the north as it becomes filled with reverberation from the uppermost of the two reflectors.

The upper faintly stratified interval correlates well with the diatom-radiolarian ooze and clayey radiolarian ooze recovered from Cores $1-5$ of Hole 303 and the zeolitic pelagic clay and chert recovered from Cores 1-5 of Hole 303A. Although some scattered chert was encountered in this latter interval, the first massive chert was recovered in Core $6 \mathrm{~A}$ and corresponds to a major decrease in the drilling rate at a subbottom depth of 253 meters. This major discontinuity corresponds probably to the uppermost part of the acoustic basement observed on the profile. This results in a calculated average interval velocity of $1.63 \mathrm{~km} / \mathrm{sec}$ for the upper interval. The sound velocity measurements performed on opened core sections (see Physical Properties, Appendix I) yielded velocities ranging from $1.5 \mathrm{~km} / \mathrm{sec}$ in the diatom-radiolarian oozes, and in the zeolitic pelagic clays, to 2.0 to $5.0 \mathrm{~km} / \mathrm{sec}$ in the chert nodules. If a $1.5 \mathrm{~km} / \mathrm{sec}$ velocity is attributed to the upper 217 meters, a velocity of about 2.8 is obtained for the lower zeolitic and chert-rich 36 meters of this upper interval.

No interval velocity can be computed from the lower interval beneath the main reflector because of the presence of heavy reverberation masking the possible presence of a lowermost reflector corresponding to the top of the basaltic basement. If we assume a sound velocity of about 3.0 for this lower interval, the top of the basalt would produce a reflector at about $0.02 \mathrm{sec}$ below the top of the acoustic basement and is undiscernible on the seismic profile. A summary of the correlation between the lithology and the seismic profile is given in Figure 5.

\section{SEDIMENTATION RATES}

The sparse recovery from Site 303 provides only a general indication of rates of sediment accumulation. The average rate for the Neogene from middle Miocene to late Pleistocene (Cores 1 to 4 ) is $16 \mathrm{~m} / \mathrm{m} . \mathrm{y}$. This moderately high rate reflects a substantial amount of biogenic and volcanogenic siliceous material.

An uncored interval of 28 meters between Neogene Core 4 and Cretaceous Cores 5 and $1 \mathrm{~A}$ to $8 \mathrm{~A}$ represents, at least, $65 \mathrm{~m} . \mathrm{y}$. Erosion is implied by the resultant small sedimentation rate $(0.4 \mathrm{~m} / \mathrm{m} . \mathrm{y}$.) for such a long period.

Sediment accumulation rates for the Cretaceous are uncertain because of the small amounts of sediment actually recovered and because of the broad age determinations. Implied rates could vary from 1 to $16 \mathrm{~m} / \mathrm{m}$.y. if accumulation were continuous. But chert formation and a possible unconformity between Cores $4 \mathrm{~A}$ and $5 \mathrm{~A}$ would make any calculations suspect.

\section{BIOSTRATIGRAPHIC SUMMARY}

\section{Cenozoic}

Only Neogene siliceous microfossils are present in samples from Cores 1 to $4(0-182 \mathrm{~m})$. Well-preserved diatoms predominate. Radiolaria and silicoflagellates are also well preserved and common. In Core 4 a dissolution sequence is present; preservation in the corecatcher sample is poor, Sections 4 to 6 is moderate, and Sections 1 to 3 is moderate to good.

\section{Mesozoic}

Radiolaria provide much of the biostratigraphic control for the Mesozoic section of Cores 5 and $1 \mathrm{~A}$ to $8 \mathrm{~A}$ $(210-284 \mathrm{~m})$. The age assignments have been determined by correlating the Radiolaria with those from Sites 305 and 306 where ages are controlled by calcareous fossils. In the Neocomian there is approximately a one-stage difference between the age assignments based on foraminifera and those based on nannoplankton. Because no value judgments can be made, the complete ranges given for both the foraminifera and the nannoplankton are used in assigning ages to the corresponding cores with Radiolaria only in Hole 303 . Therefore some rather long ranges result. Cores 5 and $1 \mathrm{~A}$ and $2 \mathrm{~A}$ are considered to be late Albian; 3A, Albian; 4A, Aptian to Barremian; and $5 \mathrm{~A}$, Barremian to Hauterivian. A distinct change in the fauna between Cores $4 \mathrm{~A}$ and $5 \mathrm{~A}$ marks the transition from the Acaeniotyle umbilicata Zone to the Eucyrtis tenuis Zone. Core 6A is considered to be Aptian or Barremian, and Cores $7 \mathrm{~A}$ and $8 \mathrm{~A}$ are considered to be Aptian to Barremian or Hauterivian.

Coccoliths and foraminifers occur only in Cores 7A to $8 \mathrm{~A}(266-284 \mathrm{~m})$ at the base of the sediment section. Benthonic foraminifer faunules from Cores $7 \mathrm{~A}$ and $8 \mathrm{~A}$ are Early Cretaceous (probably Hauterivian to Barremian). Dorothia hauteriviana is relatively frequent 

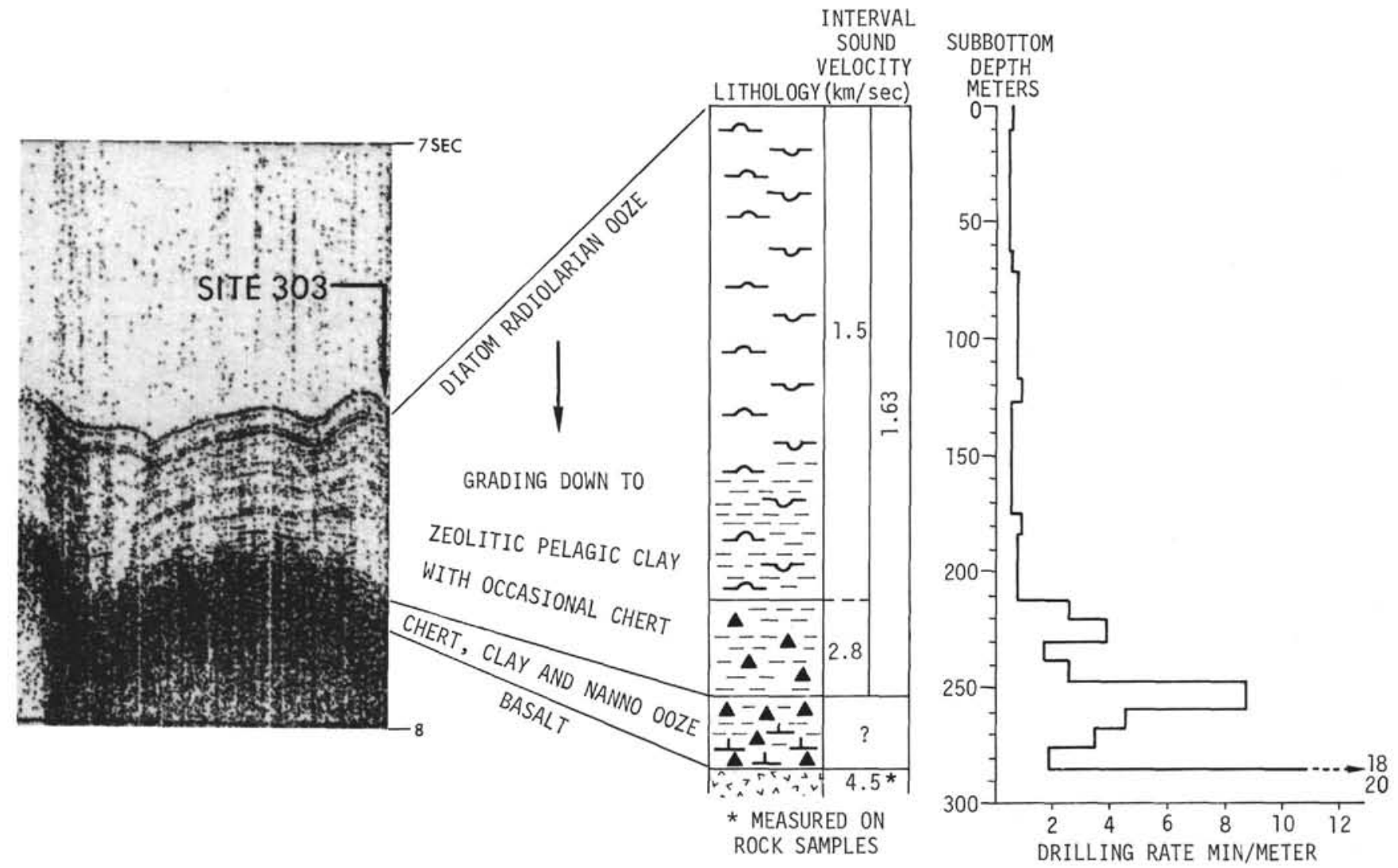

Figure 5. Correlation of seismic reflection profiles with drilling results at Site 303.

among the arenaceous foraminifers. Coccolith assemblages are most diverse and abundant in Core $8 \mathrm{~A}$, but are dominated by long-ranged, diagenetically resistant species such as Parhabdolithus embergeri and Watznaueria barnesae. The assemblage is probably Valanginian to Hauterivian based on rare Tubodiscus sp. cf. T. verenae.

\section{Foraminifera}

Cores 1 to 5 and $1 \mathrm{~A}$ to $6 \mathrm{~A}$ are carbonate free. The washed residues from the core catchers contain only a few Radiolaria, diatoms, and sponge spicules. Fragments of "Rhabdammina" are observed in Core 4.

The core-catcher sample of Core 7A contains a very poor and badly preserved faunule with Glomospira spp., Astacolus spp., Pseudonodosaria humilis and Ramulina sp. The core-catcher sample of Core $8 \mathrm{~A}$ has a poor microfauna characterized by lagenids and Dorothia spp. The presence of Dorothia hauteriviana, Dorothia sp. cf. D. praeoxycona and Corothia sp. df. D. zedlerae allows this sample to be placed into the "Interval with Dorothia hauteriviana," which is attributed to the Hauterivian or Barremian.

\section{Coccoliths}

Coccoliths are present only in the lowest two sediment cores $(266$ to $284 \mathrm{~m})$. Although they are common to abundant, preservation is poor. The assemblages are Early Cretaceous, however, many stratigraphically diagnostic species are missing. Identification of rare Tubo- discus sp. cf. T. verenae indicates a probable Valanginian or Hauterivian age (124 \pm 9 m.y.).

\section{Diatoms and Silicoflagellates}

Well-preserved, warm- and temperate-water diatom assemblages are abundant in the four discontinuously cut shallow cores between 0 and 182 meters. Silicoflagellates are meager to common in these same cores and, together with the diatoms, reflect the enduring influence of the Kuroshio Extension Current in this area. The tropical Dictyocha epidon Zone of silicoflagellates and the Roperia tessellata Zone of diatoms occur in Core $1(0-12 \mathrm{~m})$. Core 2 contains temperate-water assemblages of the Dictyocha fibula Zone of silicoflagellates. A count of 300 specimens from Sample 3032-5, 90-92 cm (69 m) includes 50\% Distephanus speculum speculum, 13\% Dictyocha fibula, 9\% D. rhombica, 9\% Mesocena elliptica, 4\% Distephanus boliviensis, 3\% D. speculum pentagonus, 2\% Mesocena diodon, $1 \%$ Dictyocha aspera, 2\% Distephanus speculum binoculus, $4 \%$ Mesocena circulus, 2\% Distephanus crux, and less than $1 \%$ D. speculum quintus. The high proportion of Distephanus specimens in the assemblage indicates temperate water conditions.

Late Miocene diatoms and silicoflagellates in Core 3 $(117-126 \mathrm{~m})$ are excellently preserved. The presence of Thalassiosira convexa and the predominance of Dictyocha aspera and D. rhombica over D. fibula indicates the upper Dictyocha aspera Zone. A high proportion of Dictyocha to Distephanus specimens indicates warm- 
water deposition. A count of 303 silicoflagellate specimens in Sample 303-3-5, 30-32 cm (123 m) includes 34\% Dictyocha aspera, 20\% D. rhombica, 19\% Distephanus speculum speculum, 16\% Dictyocha fibula, $10 \%$ Naviculopsis quadratus, and less than 1\% each Distephanus boliviensis and D. speculum quintus.

In Core 4 (173-182 m) Dictyocha aspera is also predominant, however, the occurrence of the diatoms Asteromphalus moroensis and Coscinodiscus plicatus suggest the lower part of Dictyocha aspera Zone which is early late Miocene or middle Miocene in age.

Diatoms and silicoflagellates are absent in deeper cores from this site.

\section{Radiolaria}

Unless otherwise stated, only core-catcher samples were examined for this report.

\section{Neogene}

Only siliceous fossils are present in the Neogene Cores 1-4 recovered from Hole 303. Radiolaria are common and well preserved in all of them.

Core 1, at a depth of 0-12 meters below the sediment surface, is late Quaternary Artostrobium tumidulum Zone. Core 2, at a depth of 62-71 meters early Pliocene, Stichocorys peregrina. Cores 3 and 4, at a depth of 117 126 meters and 173-182 meters, respectively, are below the range of Hays' (1970)zonation for the North Pacific, and the age determination is made on the basis of the Riedel and Sanfilippo (1971) equatorial zonation: Core 3, late Miocene, Stichocorys peregrina Zone and Core 5, late Miocene, Ommatartus antepenultimus Zone.

\section{Mesozoic}

Samples of both clay and chert were examined. In general, the Radiolaria are better preserved in the chert and unless otherwise stated, age assignments have been made from these samples.

Radiolaria were recovered from Core 5 in Hole 303 and Cores 1 A-8A in Hole 303A and age assignments are made on the basis of correlations with radiolarian events in Holes 305 and 306 which have calcareous fossil control (see Foreman, fig. 1, this volume). No other siliceous fossils were observed.

Cores 5 and IA at depths of 211-220 meters, and Core $2 \mathrm{~A}$ at 220-229 meters, contain few poorly preserved to moderate Radiolaria which are considered to be Cenomanian or late Albian, and late Albian, respectively. All belong to the Dictyomitra somphedia Zone. Cores $3 \mathrm{~A}(229-238 \mathrm{~m})$ with few, poor Radiolaria, and 4A (238$247 \mathrm{~m}$ ) with common, moderate Radiolaria, are Albian, and Aptian or Barremian, and are assigned to the Acaeniotyle umbilicata Zone. An abrupt change in the fauna from Cores $4 \mathrm{~A}$ to $5 \mathrm{~A}$ marks the transition to the Eucyrtis tenuis Zone. The remaining Cores 6A to 8A all belong to this zone. Cores $5 \mathrm{~A}(247-257 \mathrm{~m})$ with common poor and $6 \mathrm{~A}(257-266 \mathrm{~m})$ with common moderate Radiolaria are Aptian to Barremian and Aptian to Barremian or Hauterivian, respectively. Cores 7A (266$275 \mathrm{~m})$ and $8 \mathrm{~A}(275-284 \mathrm{~m})$ contain a fauna similar to, but sparser and more poorly preserved than that in Core $6 \mathrm{~A}$. Table 4 summarizes the biostratigraphic data.

\section{SUMMARY AND CONCLUSIONS}

Figure 6 shows a summary of the coring, lithology, biostratigraphy, and physical properties of Site 303. The most significant discovery at Site 303 is the Early Cretaceous age of the sediments overlying basement. The east-northeast-striking Japanese linear magnetic anomalies therefore cannot be any part of the latest Cretaceous to present-day magnetic reversal sequence that has been reported in all the major oceans. Rather, as predicted, the Japanese lineations correlate with the Phoenix lineations (Site 166).

There was little recovery of fossiliferous sediment in the lower part of Hole 303A, and this combined with multistage microfossil range determinations make it difficult to establish age limits more exactly than Valanginian to Barremian. The calcareous microfossil ranges overlap in the Hauterivian so this is the most likely age in the average sense. This is very close to the age predicted (early Barremian) for anomaly $\mathrm{M}-4$, but the lack of precise age determination indicates that drilling of additional sites, or refinement of biostratigraphic correlations between Europe and the Pacific will be necessary for calibration of the Larson and Pitman model of Cretaceous spreading rates.

The actual contact of sediment on basalt was not recovered, but as it is known within 2 meters, it seems unlikely that the missing sediment (which is more than $10 \mathrm{~m}$ thick) can be significantly older than what was recovered. Even though the contact could not be examined, there can be little doubt that the basalt is of extrusive origin. The uppermost core is very fine grained and variolitic, and that texture is repeated at several intervals through the basalt cores, indicating several cooling units of pillows or successive flows.

Very little amorphous ferromanganese-rich mud and no hyaloclastite was recovered in the lower part of the section of generally poor recovery, and so the question remains whether processes that have formed those sediments so commonly in the central and eastern Pacific were active at Site 303.

The poor recovery also restricts the value of this site for interpreting paleodepths and the passage of the Pacific plate under the equator; however, good remnant magnetic inclination measurements on the basalts (Larson and Lowrie, this volume) indicate that this site was formed at about $6^{\circ}$ south latitude. This was probably just south of the equatorial zone of productivity present at that time. While very little is known about the depression of the CCD beneath the Cretaceous equator, it is reasonable to assume that the ridge had subsided enough before its subsequent transit under the equator that carbonate was dissolved, and radiolarians, now chert, were deposited.

Chert is a component of all cores below 211 meters and is especially massive at 253 meters where it forms the lowermost seismic reflector at the site. There may be some relationship between the possible mid-Cretaceous stratigraphic break based on radiolarians and the development of chert.

The greatly compressed section or unconformity between the Cenomanian and the Miocene is the most important break in the stratigraphic history of the site. 
TABLE 4

Distribution, Age, and Frequency of Investigated Microfossils

\begin{tabular}{|c|c|c|c|c|c|c|c|c|c|}
\hline \multirow[b]{2}{*}{ ¿ } & \multirow[b]{2}{*}{ Depth (m) } & \multirow{2}{*}{ 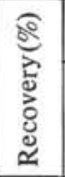 } & \multicolumn{3}{|c|}{ Foraminifera } & \multirow{2}{*}{\multicolumn{2}{|c|}{$\begin{array}{c}\text { Calcareous } \\
\text { Nannoplankton }\end{array}$}} & \multirow{2}{*}{\multicolumn{2}{|c|}{ Radiolaria }} \\
\hline & & & 尝 & 节 & & & & & \\
\hline 1 & $0.0-12.0$ & 5 & - & - & - & - & - & o & $\begin{array}{l}\text { Late } \\
\text { Pleistocene }\end{array}$ \\
\hline 2 & $62.0-71.0$ & 100 & - & - & - & - & - & o & Early Pliocene \\
\hline 3 & $117.0-126.0$ & 89 & - & - & - & - & - & o & Late Miocene \\
\hline 4 & $174.0-183.0$ & 92 & - & + & - & - & - & * & Late Miocene \\
\hline 5 & $211.0-220.0$ & $<1$ & - & - & - & - & - & + & $\begin{array}{l}\text { Cenomanian } \\
\text { or late Albian }\end{array}$ \\
\hline 6 & $220.0-229.0$ & 0 & - & - & - & - & - & - & - \\
\hline $1 \mathrm{~A}$ & $211.0-220.0$ & $<1$ & - & - & - & - & - & + & $\begin{array}{l}\text { Cenomanian } \\
\text { or late Albian }\end{array}$ \\
\hline $2 \mathrm{~A}$ & $220.0-229.25$ & $<1$ & - & - & - & - & - & $*$ & Late Albian \\
\hline $3 \mathrm{~A}$ & $229.25-238.50$ & 2 & - & - & - & - & - & $*$ & Albian \\
\hline $4 \mathrm{~A}$ & $238.50-247.75$ & 4 & - & - & - & - & - & * & $\begin{array}{l}\text { Aptian/ } \\
\text { Barremian }\end{array}$ \\
\hline $5 \mathrm{~A}$ & $247.75-257.0$ & 16 & - & - & - & - & - & o & $\begin{array}{l}\text { Barremian/ } \\
\text { Hauterivian }\end{array}$ \\
\hline $6 \mathrm{~A}$ & $257.0-266.25$ & 4 & - & - & - & - & - & o & $\begin{array}{l}\text { Aptian to } \\
\text { Barremian/ } \\
\text { Hauterivian }\end{array}$ \\
\hline $7 \mathrm{~A}$ & $266.25-275.50$ & 5 & - & + & - & o & $\begin{array}{l}\text { Hauterivian/ } \\
\text { Valanginian }\end{array}$ & * & $\begin{array}{l}\text { Aptian to } \\
\text { Barremian/ } \\
\text { Hauterivian }\end{array}$ \\
\hline $8 \mathrm{~A}$ & $275.50-284.75$ & 4 & - & + & $\begin{array}{l}\text { Barremian/ } \\
\text { Hauterivian }\end{array}$ & $\bullet$ & $\begin{array}{l}\text { Hauterivian/ } \\
\text { Valanginian }\end{array}$ & + & $\begin{array}{l}\text { Aptian to } \\
\text { Barremian/ } \\
\text { Hauterivian }\end{array}$ \\
\hline $9 \mathrm{~A}$ & $284.75-288.0$ & 46 & & & SALT & & & & \\
\hline $10 \mathrm{~A}$ & $288.0-293.0$ & 20 & & & SAL1 & & & & \\
\hline
\end{tabular}

Note: • abundant; o common; * frequent; + rare; - absent.

There is no indication on the airgun records, either of a "hard ground" reflector, or of thickening or thinning in that part of the section in adjacent areas that might help one to decide whether an actual erosional unconformity is present.

The Neogene section is rich in siliceous fossils. Unfortunately, time did not allow us to take more than a few cores in the upper part of Hole 303 and none there in Hole $303 \mathrm{~A}$. The great abundance of diatoms, radiolarians, and silicoflagellates suggests that the mixing boundary between the Kuroshio and Oyashio currents has been in the vicinity of Site 303 for the past 15 m.y.

Several of the topics considered above are also discussed in the Site 304 chapter that follows, along with a comparison of the two sites and an illustration of the fossil ranges involved.

\section{REFERENCES}

Bass, M. N., Moberly, R., Rhodes, J. M., Shih, C., and Church, S. E., 1973. Volcanic rocks cored in the Central Pacific, Leg 17, Deep Sea Drilling Project. In Winterer, E. L., Ewing, J. I., et al., Initial Reports of the Deep Sea Drilling Project, Volume 17: Washington (U. S. Government Printing Office), p. 429-503.
Chase, T. E., Menard, H. W., and Mammerickx, J., 1971 Topography of the North Pacific. Institute of Marine Resources, University of California, San Diego.

Hays, J. D., 1970. Stratigraphy and evolutionary trends of Radiolaria in North Pacific sediments: Geol. Soc. Am., Mem. 126, p. 185-218.

Hays, J. D. and Pitman, W. C., III, 1973. Lithospheric plate motion, sea level changes and climatic and ecological consequences: Nature, v. 246, p. 18-22.

Larson, R. L. and Chase, C. G., 1972. Late Mesozoic evolution of the Western Pacific: Geol. Soc. Am. Bull., v. 83, p. 3627-3644.

Larson, R. L. and Pitman, W. C., III, 1972. Worldwide correlation of Mesozoic magnetic anomalies, and its implications: Geol. Soc. Am. Bull., v. 83, p. 3645-3662.

Lowrie, W., Opdyke, N. O., and Lovlie, R., 1973. Magnetic properties of DSDP basalts from the Pacific Ocean (abstract): E.O.S. (Am. Geophys. Union Trans.), v. 54, p. 256.

Riedel, W.R. and Sanfilippo, A., 1971. Cenozoic Radiolaria from the western tropical Pacific, Leg 7. In Winterer, E.L., Riedel, W.R., et al., Initial Reports of the Deep Sea Drilling Project, Vol. 2: Washington (U.S. Government Printing Office), p. 1529-1672.

Salisbury, M. H. and Christensen, N. I., 1972. Velocity-density systematics for JOIDES basalts (abstract): Geol. Soc. Am., Abstracts with programs, v. 4 , p. 228. 


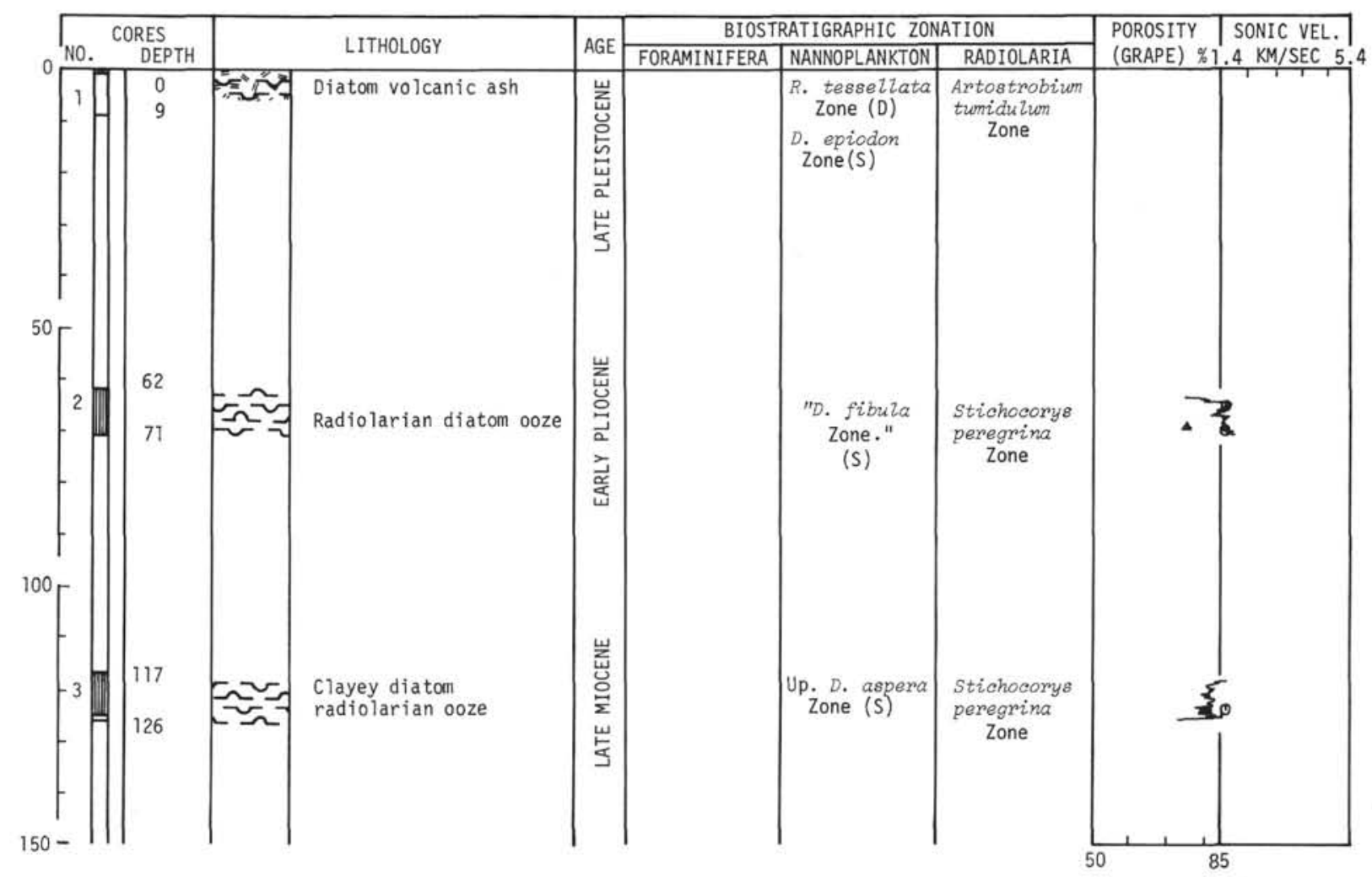

Figure 6. Summary of coring, lithology, biostratigraphy, and physical properties at Site 303.

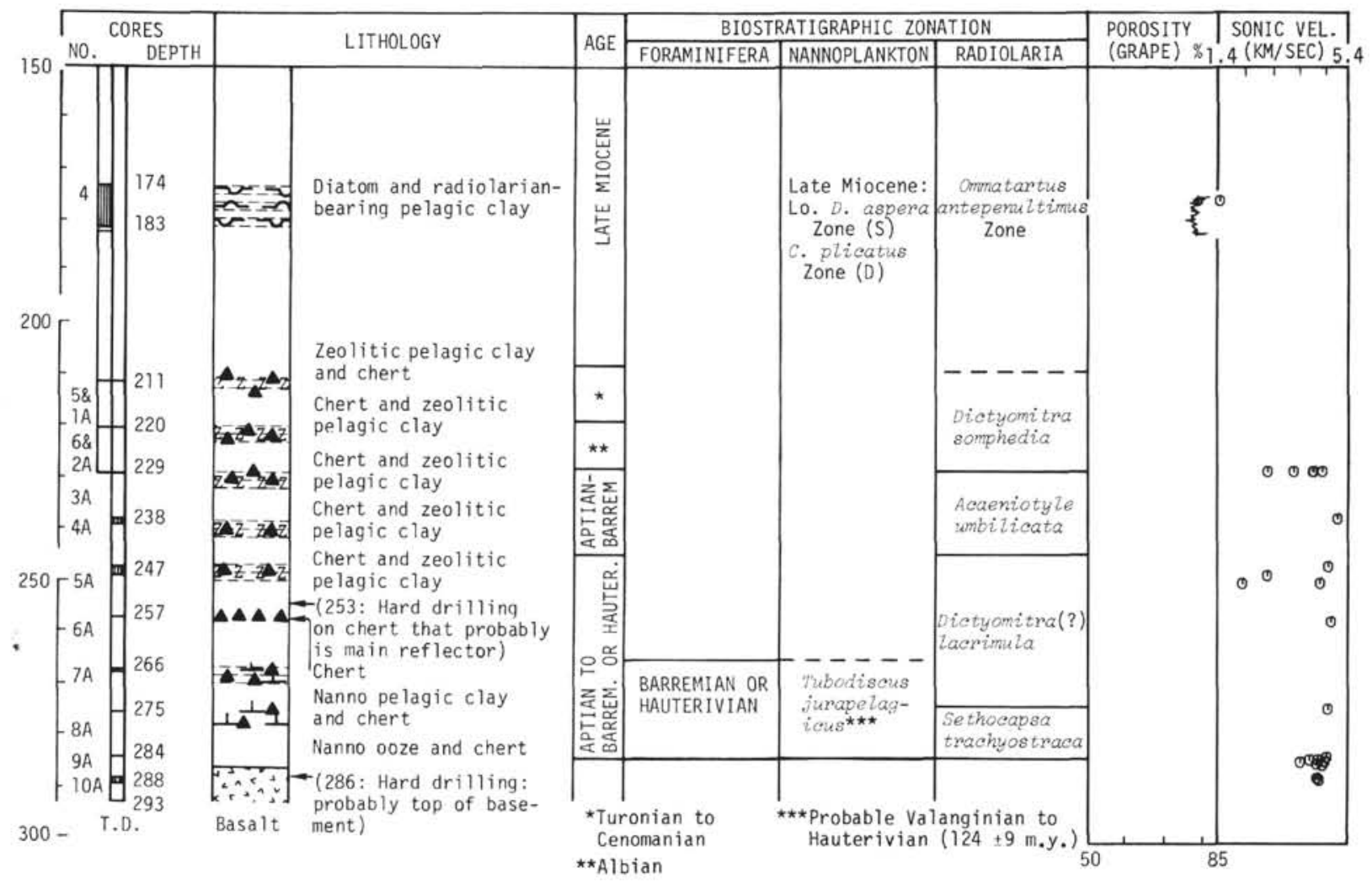

Figure 6. (Continued). 


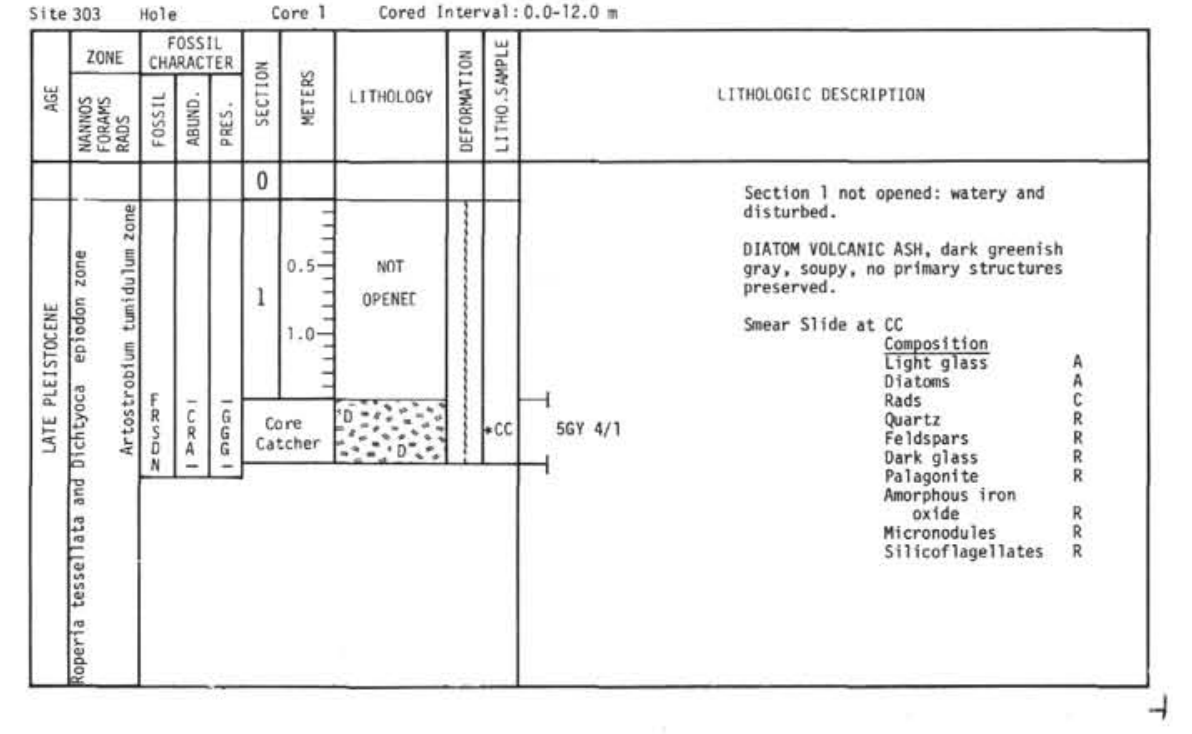

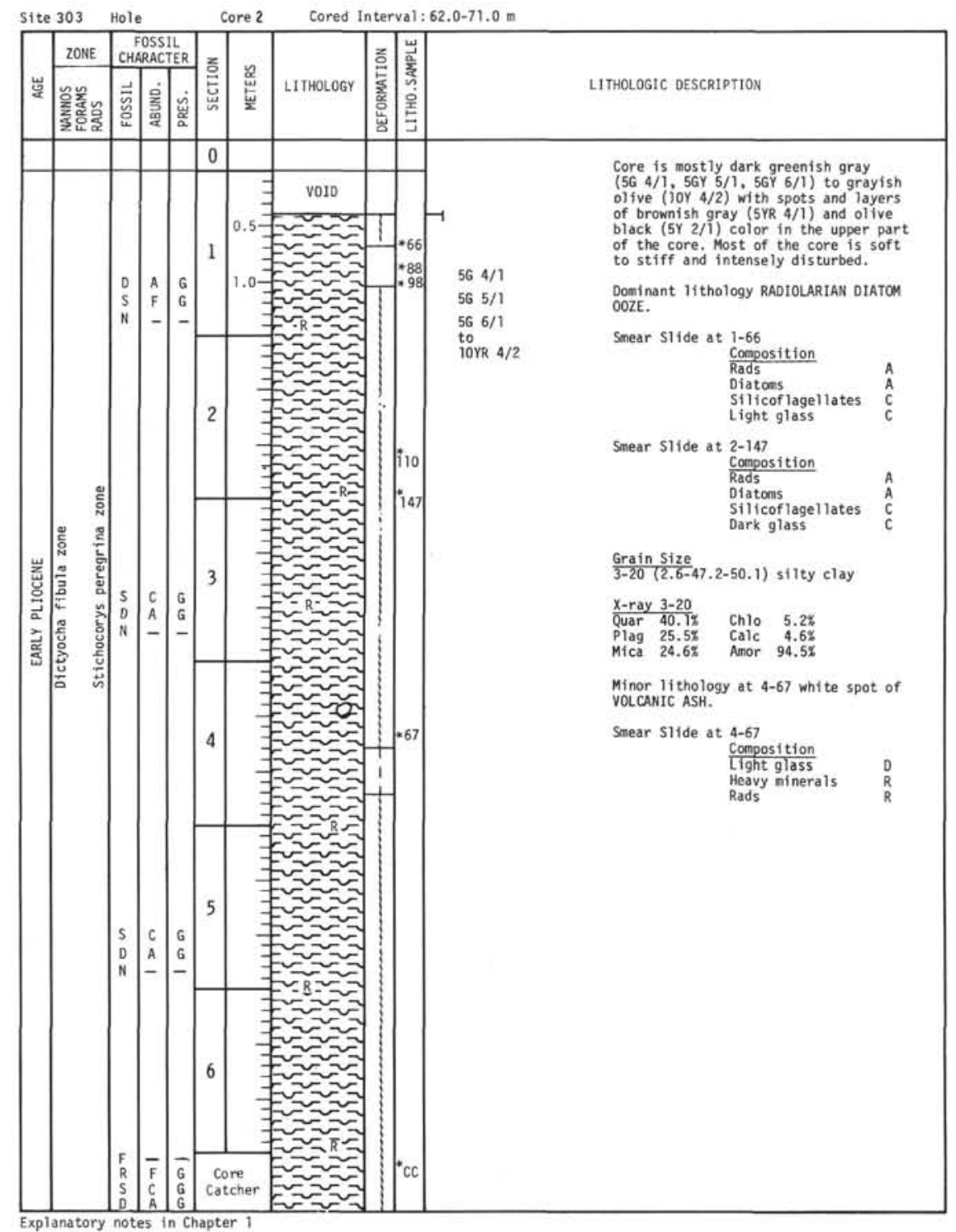




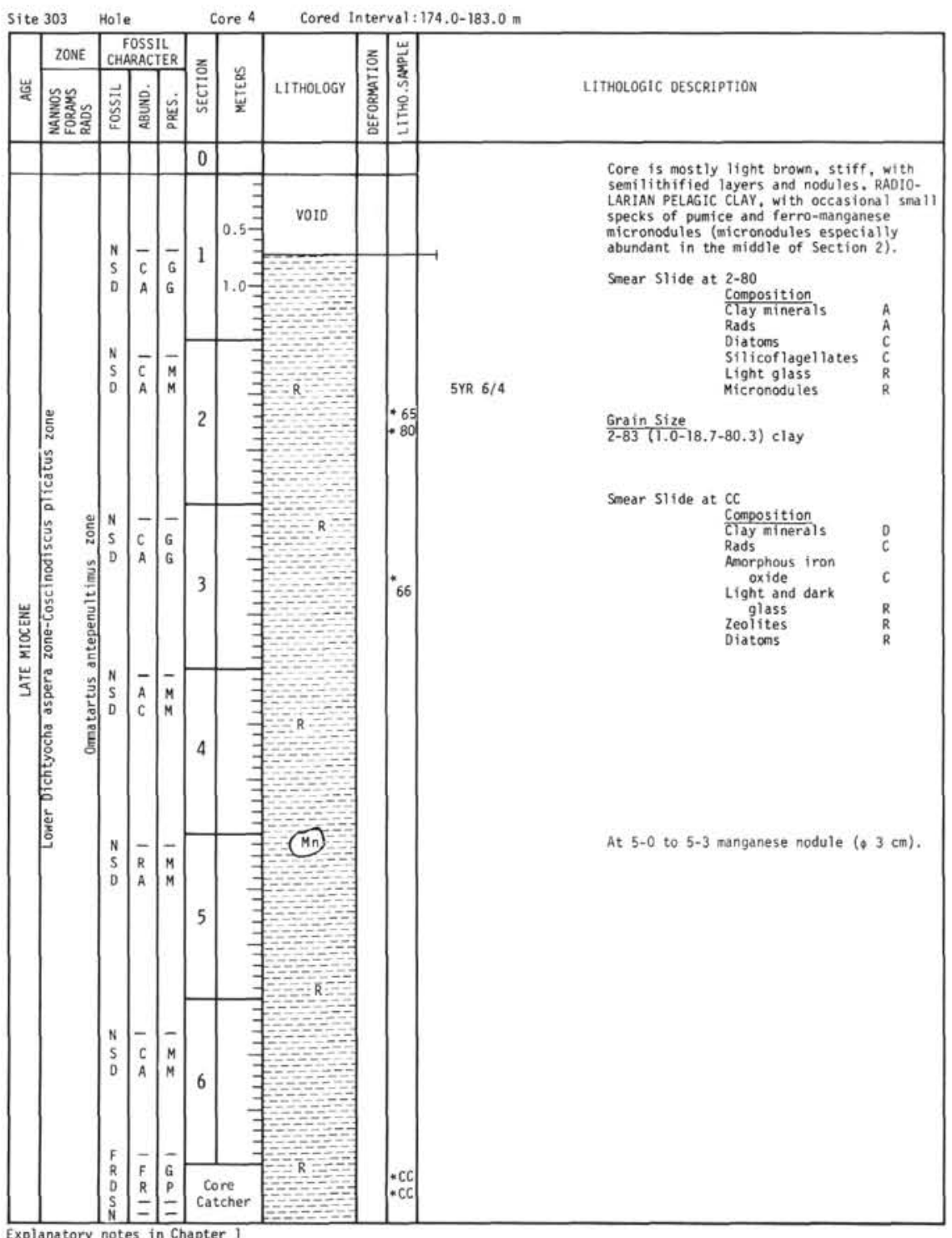



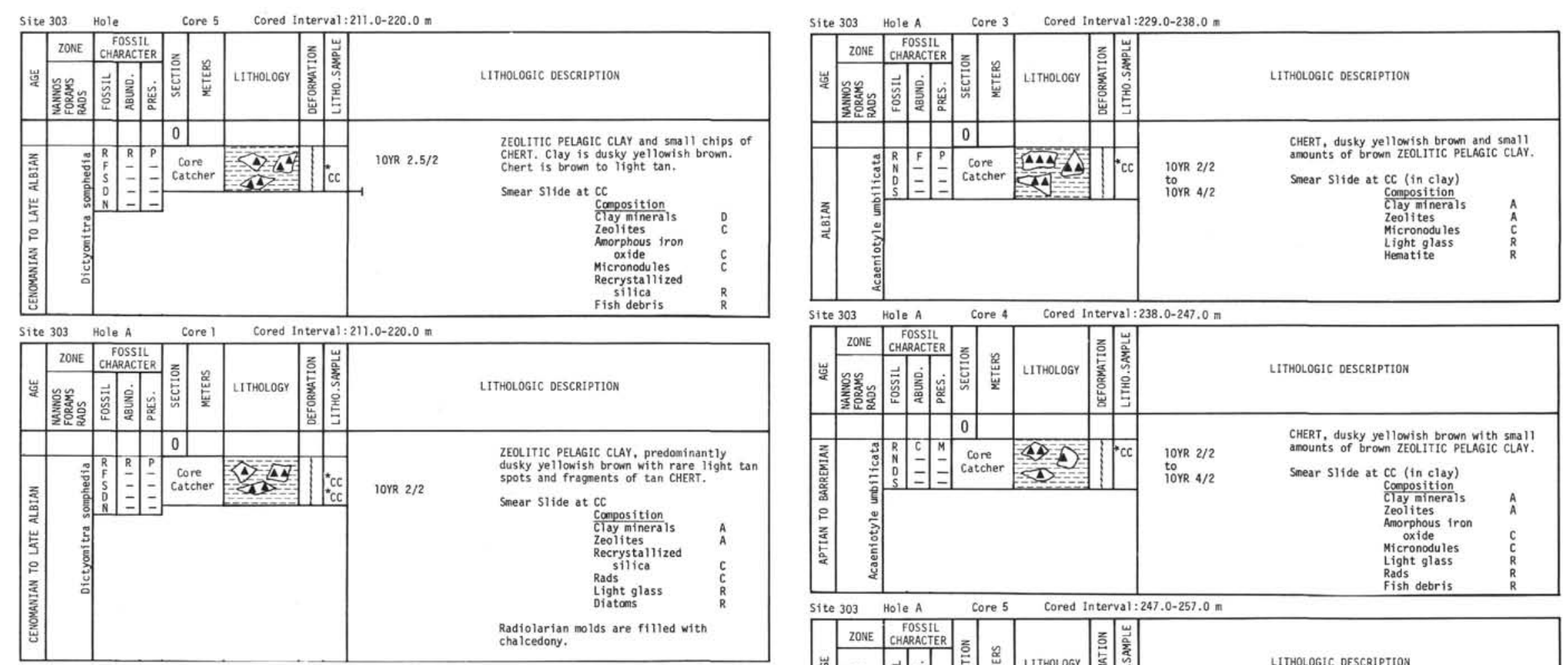

\section{Site 303 Hole A Core 2 Cored Interval:220.0-229.0 m}

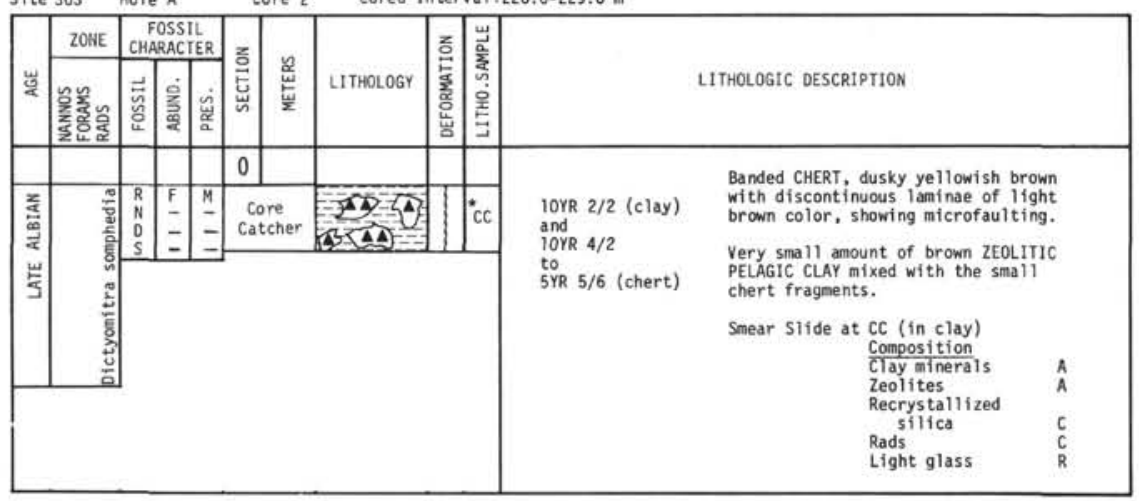




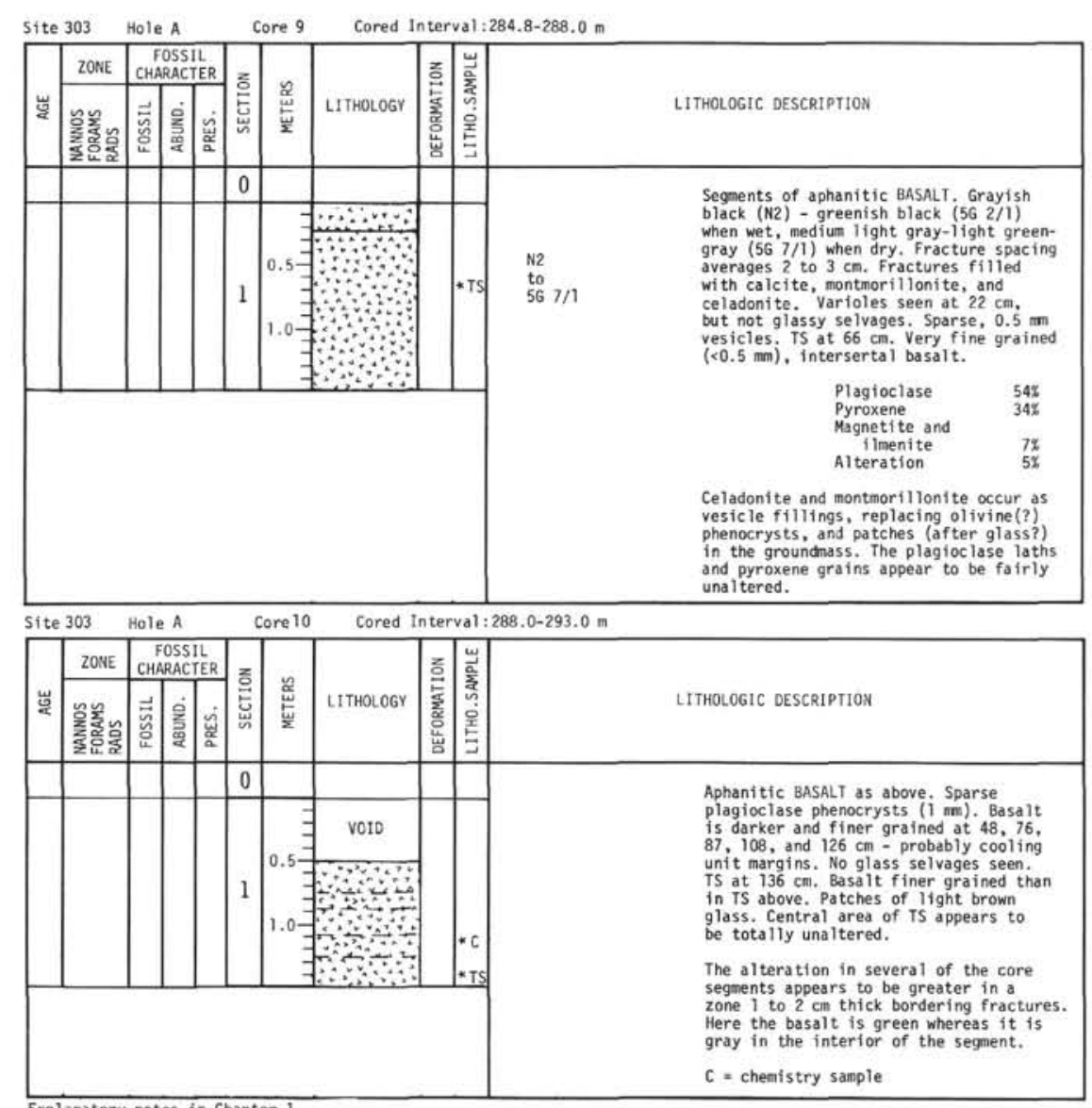


CORE 303-2

$-=$ GRAPE WET-BULK DENSITY, g/CC

- Syringe porosity, \% COMPRESSIONAL SOUND VELOCITY

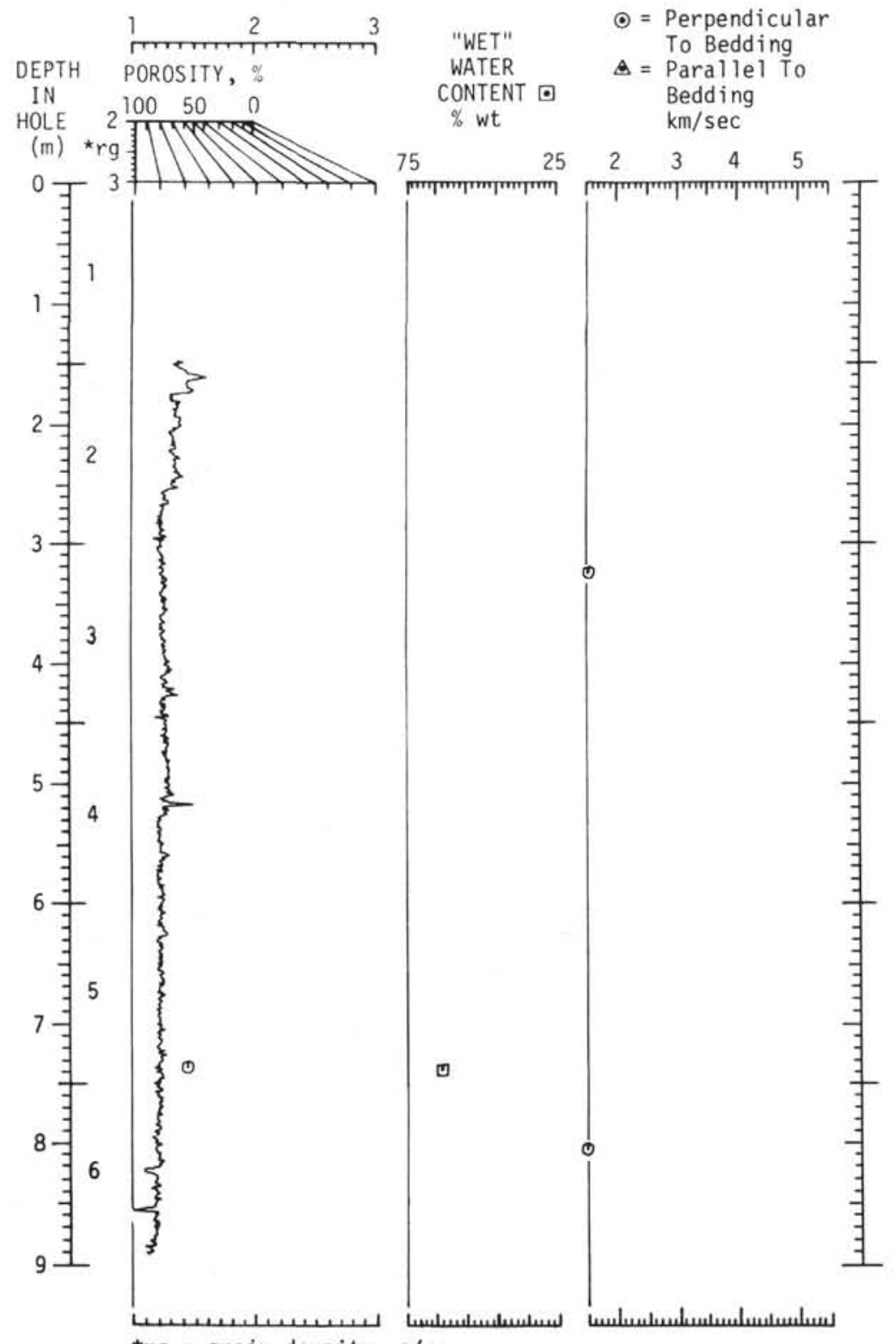

CORE 303-3

- = GRAPE WET-BULK DENSITY, g/cC

- Syringe porosity, \% COMPRESSIONAL SOUND VELOCITY

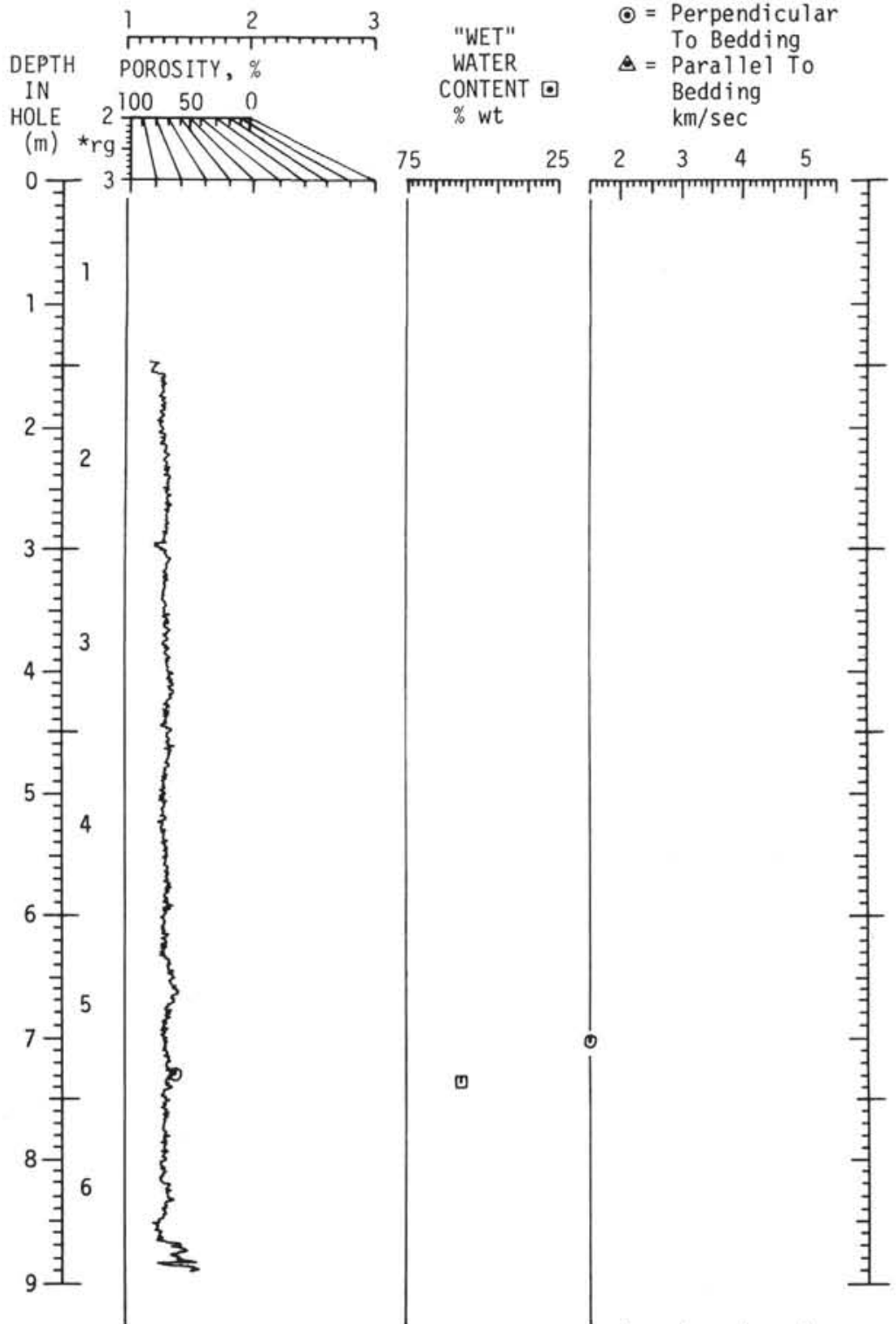

$\star^{\star} r g=$ grain density, $g / c c$

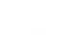


- Syringe porosity, \% COMPRESSIONAL SOUND VELOCITY

WET-BULK DENSITY, $g / c c$

- Syringe porosity, \% COMPRESSIONAL SOUND VELOCITY
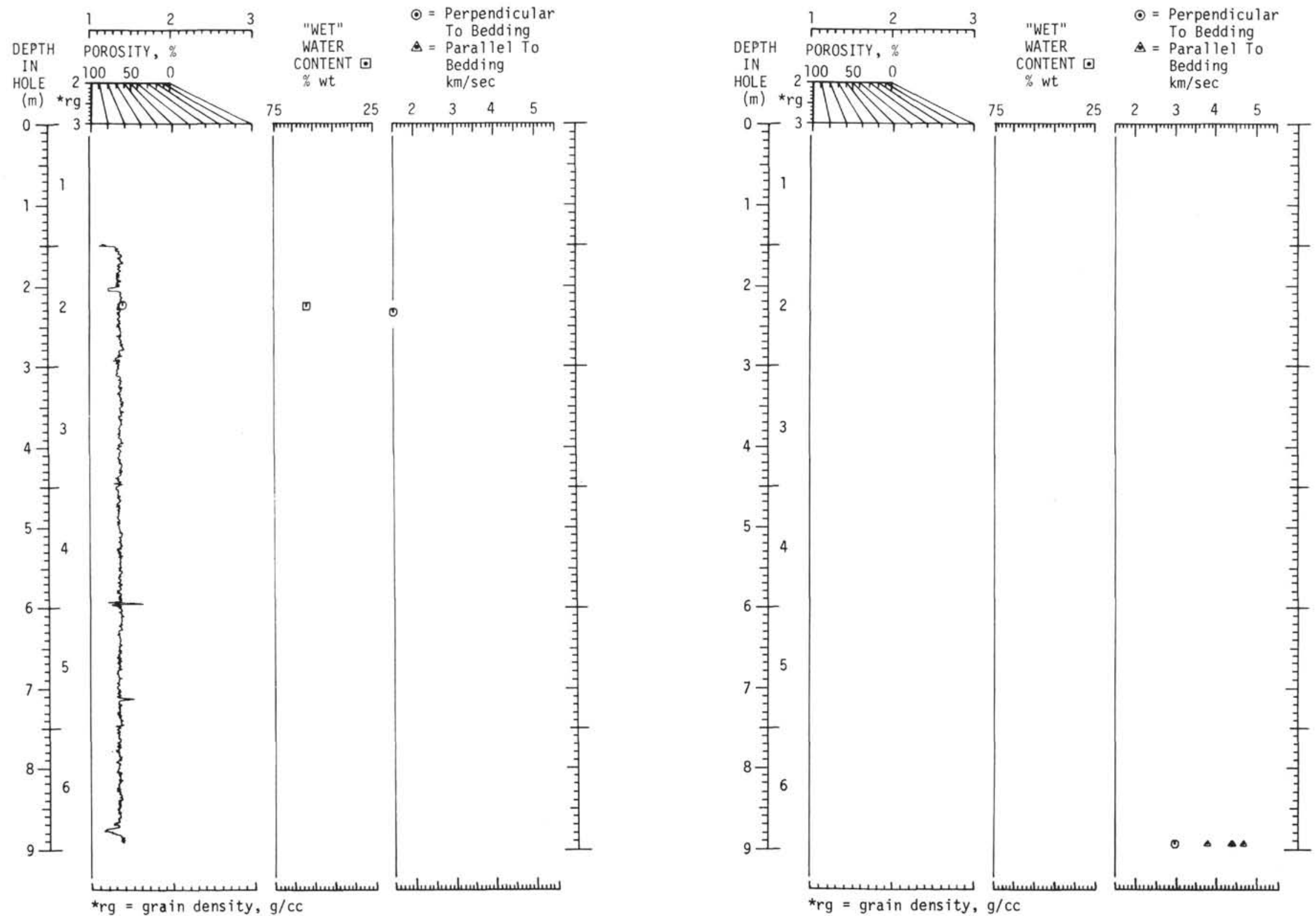
CORE $303 \mathrm{~A}-3$

- $=$ GRAPE WET-BULK DENSITY, g/cC

- Syringe porosity, \% COMPRESSIONAL SOUND VELOCITY

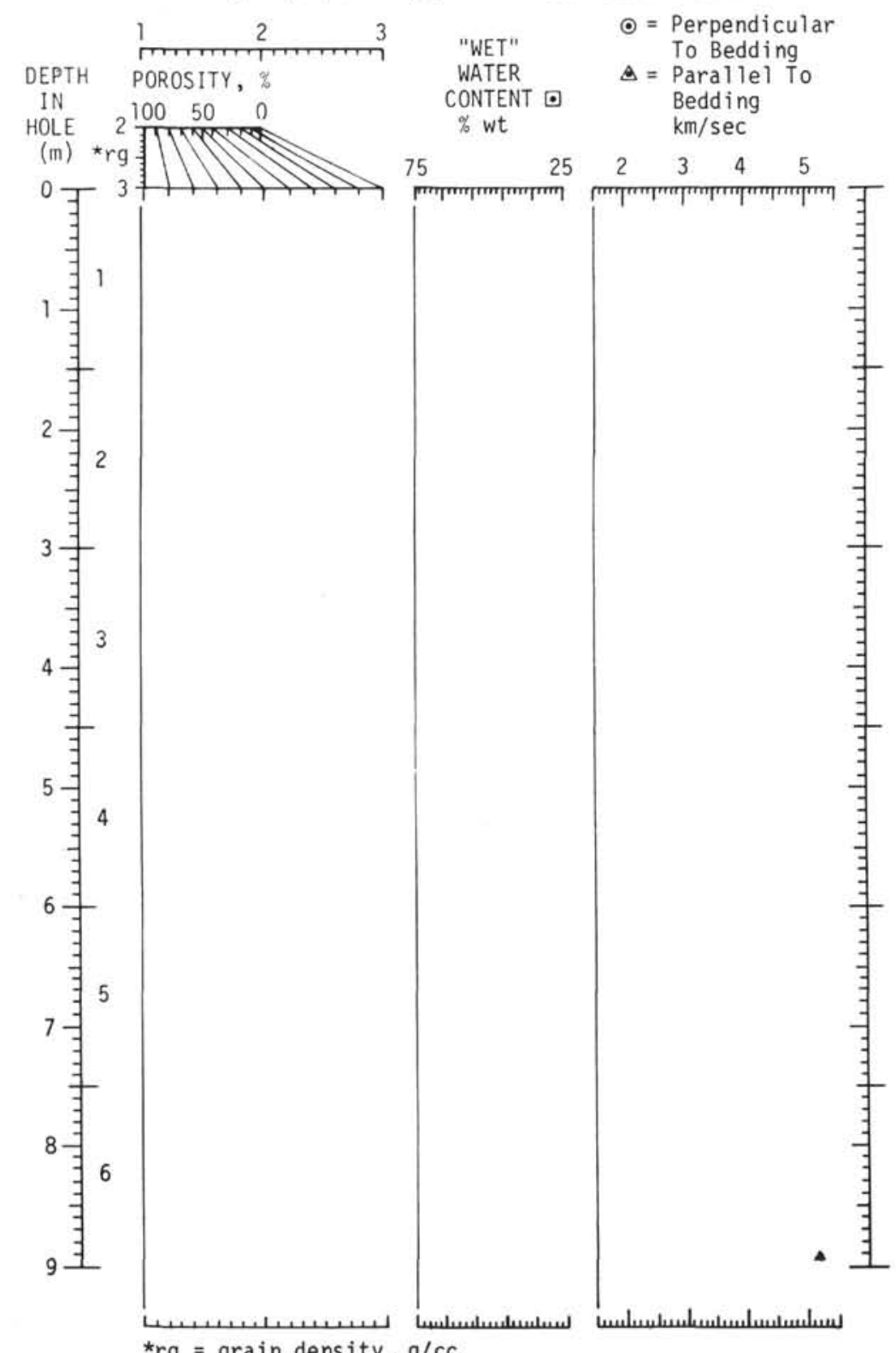

CORE 303A-4

- $=$ GRAPE WET-BULK DENSITY, $\mathrm{g} / \mathrm{cC}$

- Syringe porosity, \% COMPRESSIONAL SOUND VELOCITY

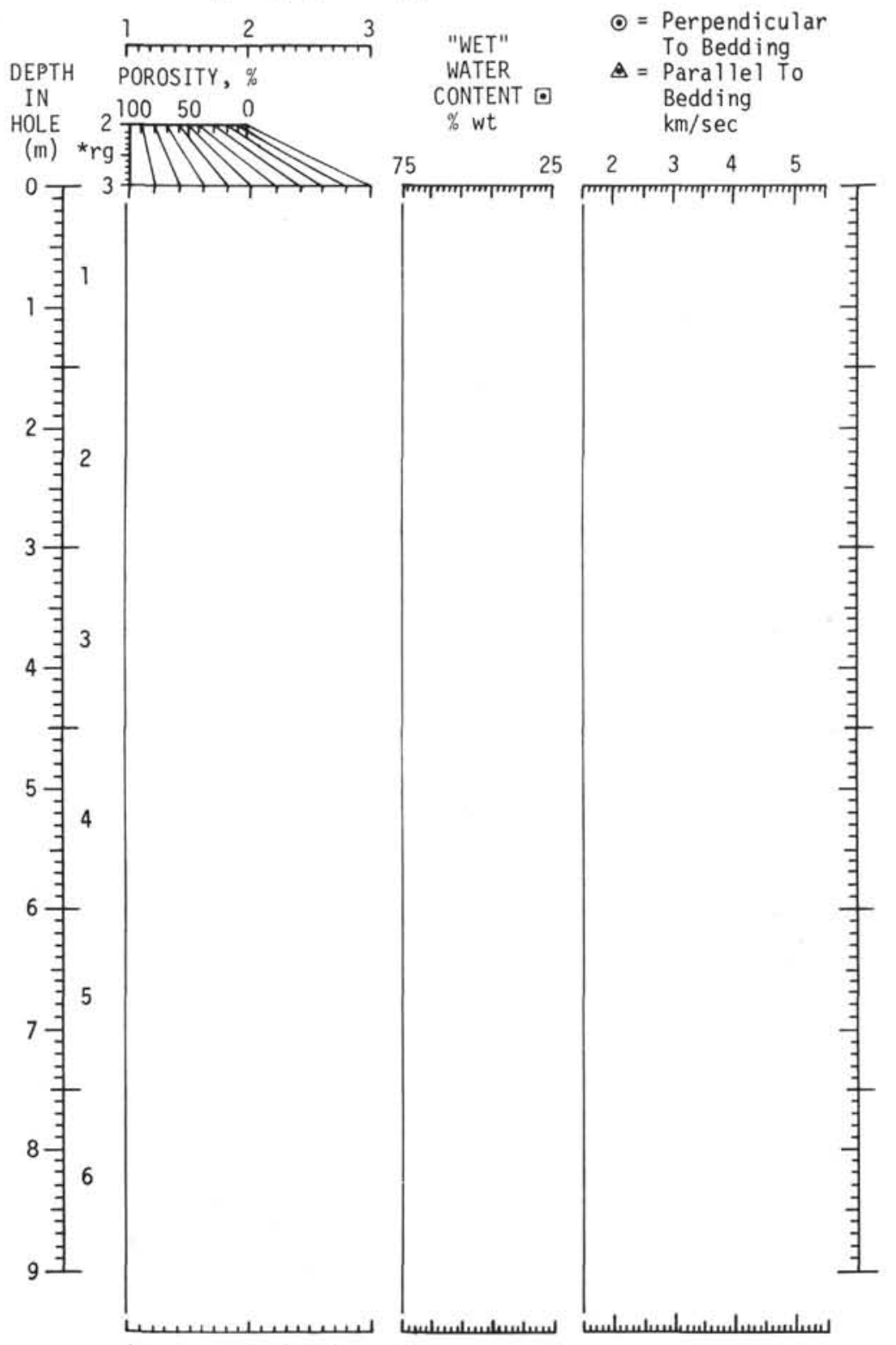


- Syringe porosity, \% COMPRESSIONAL SOUND VELOCITY

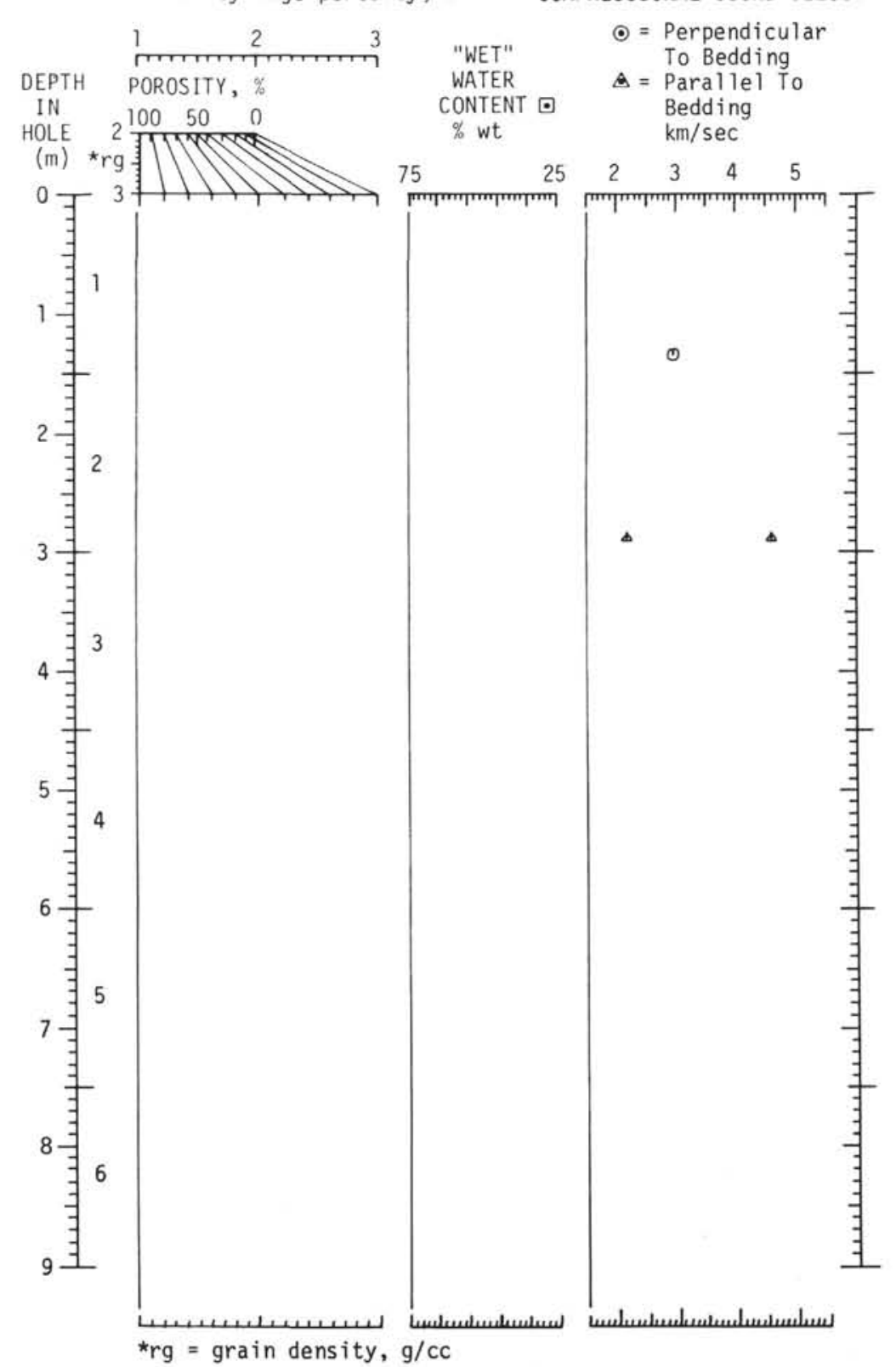

- Syringe porosity, \% COMPRESSIONAL SOUND VELOCITY
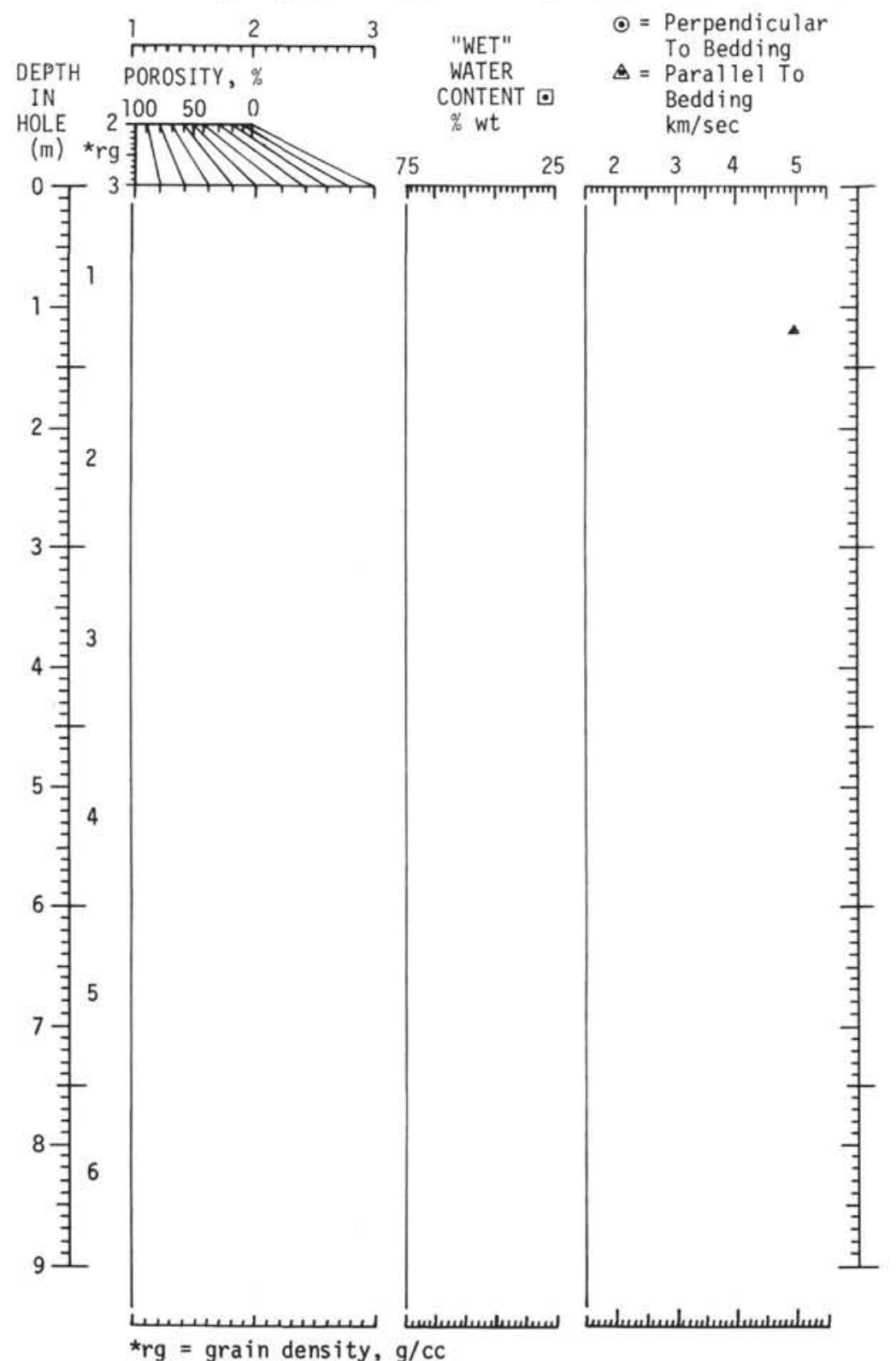
CORE $303 \mathrm{~A}-7$

- $=$ GRAPE WET-BULK DENSITY, $g / C C$

- Syringe porosity, \% COMPRESSIONAL SOUND VELOCITY

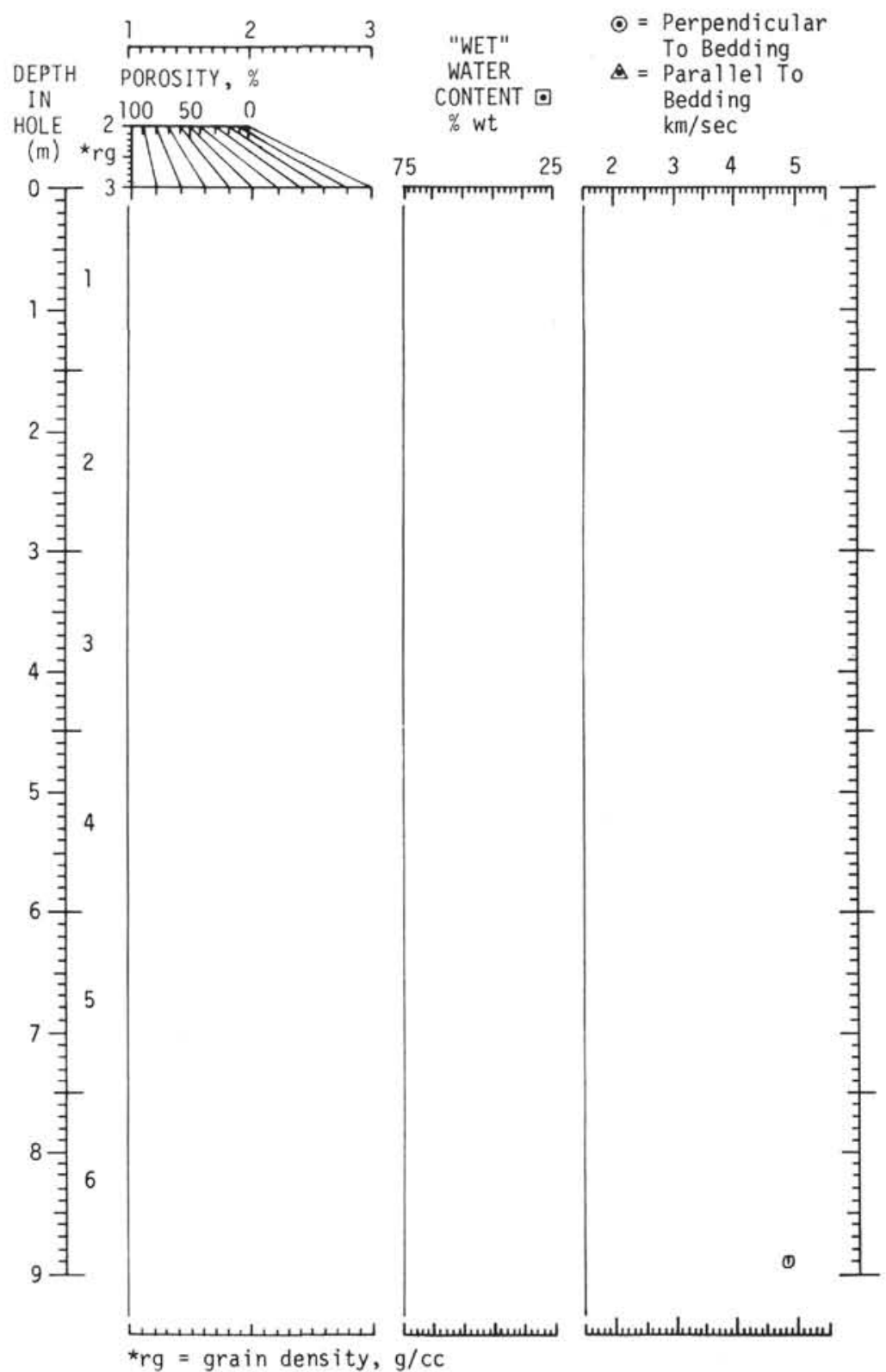

CORE 303A-8

- = GRAPE WET-BULK DENSITY, g/cC

- Syringe porosity, \% COMPRESSIONAL SOUND VELOCITY

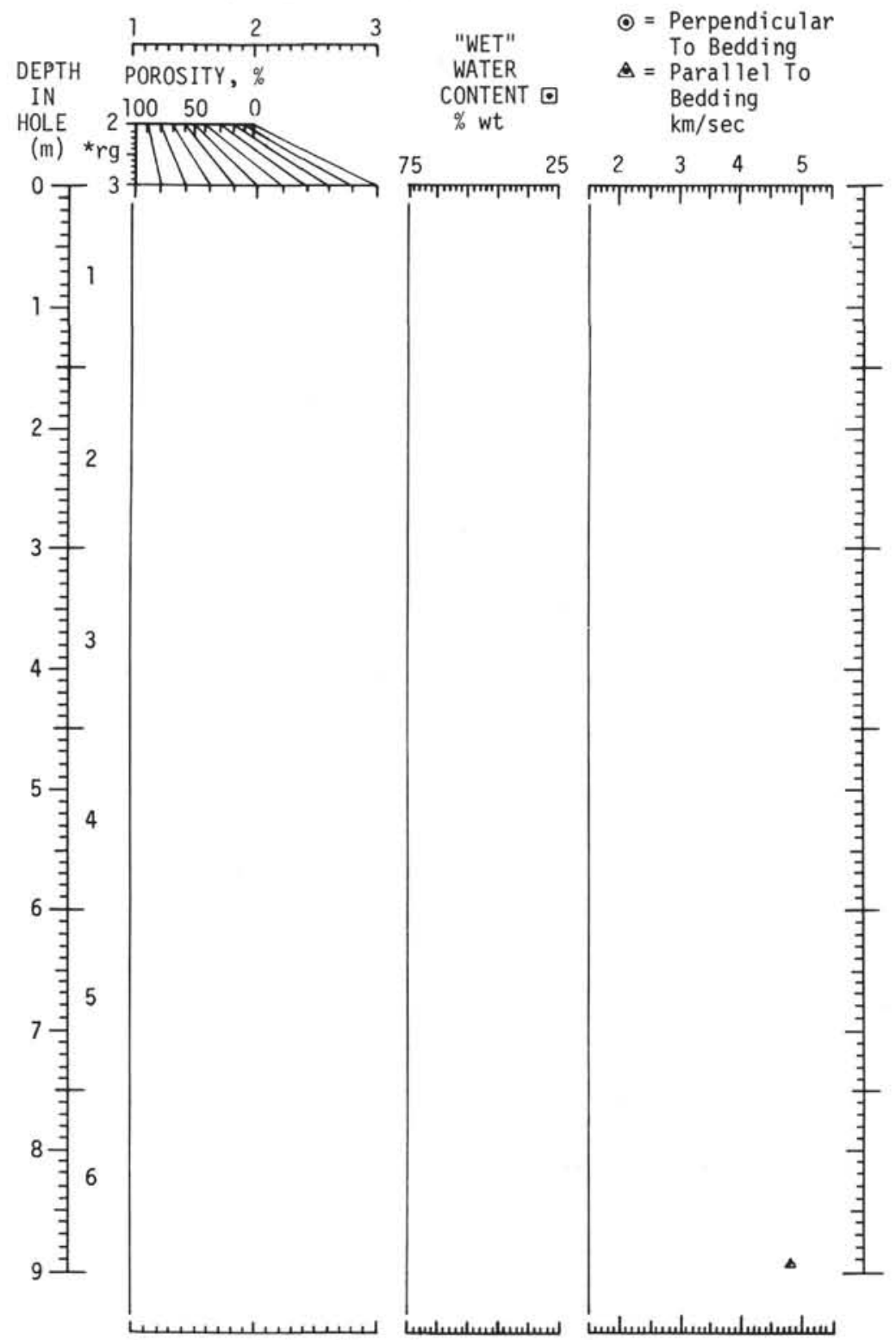

${ }^{*}$ rg $=$ grain density, $g / c c$ 
- Syringe porosity, \% COMPRESSIONAL SOUND VELOCITY

$=$ GRAPE WET - BULK DENSITY, $g / c C$

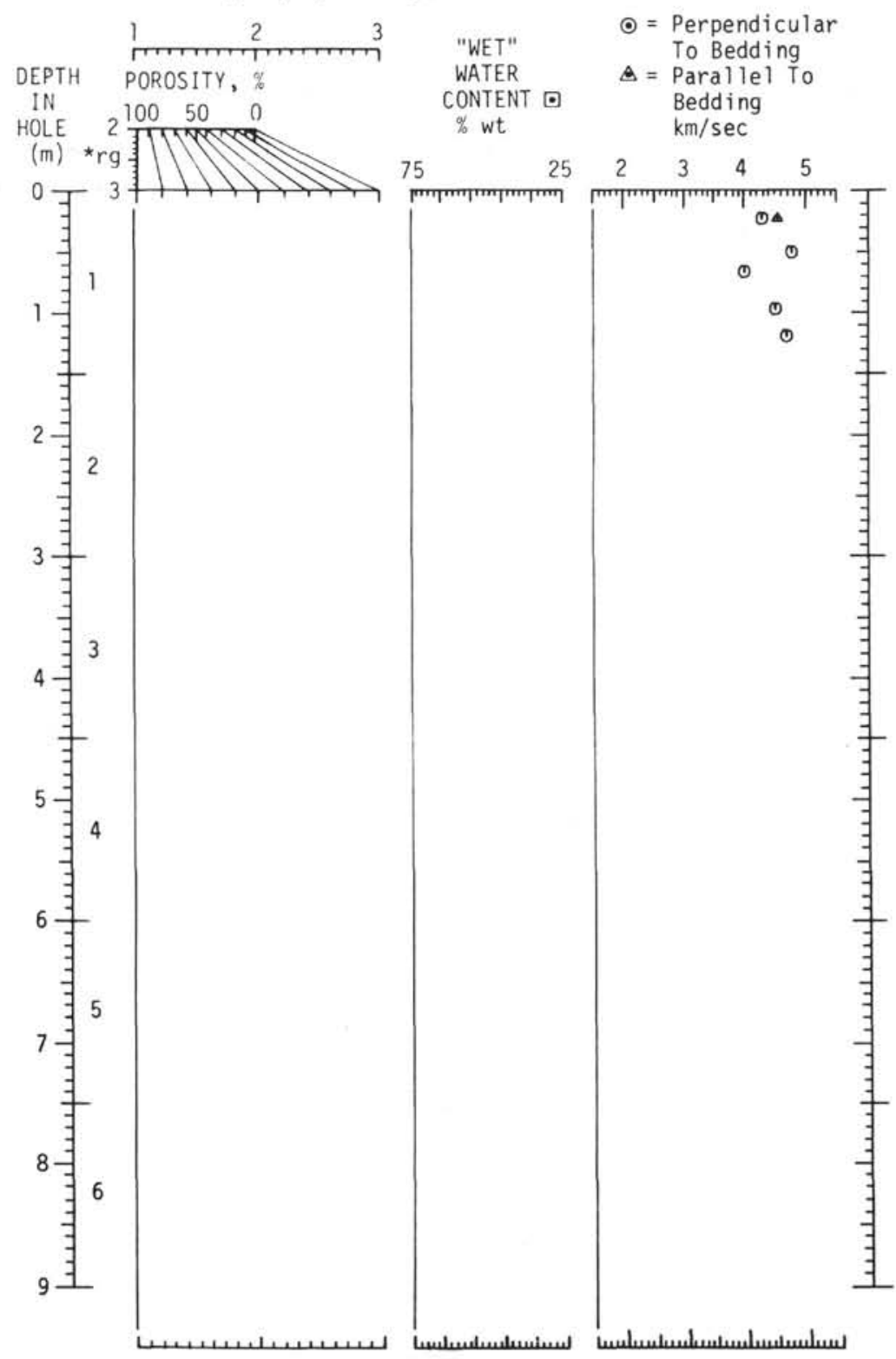

๑ Syringe porosity, \% COMPRESSIONAL SOUND VELOCITY

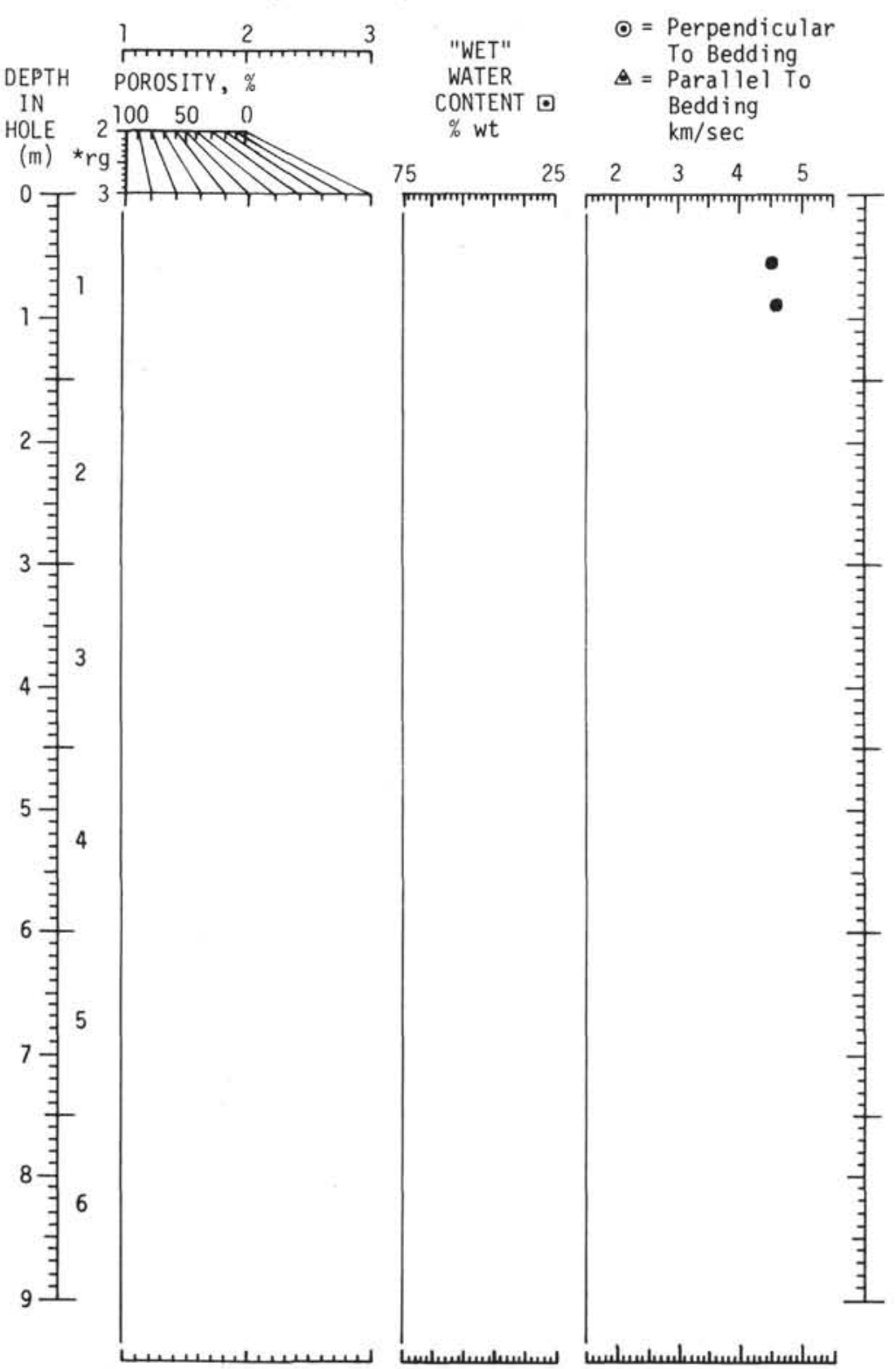




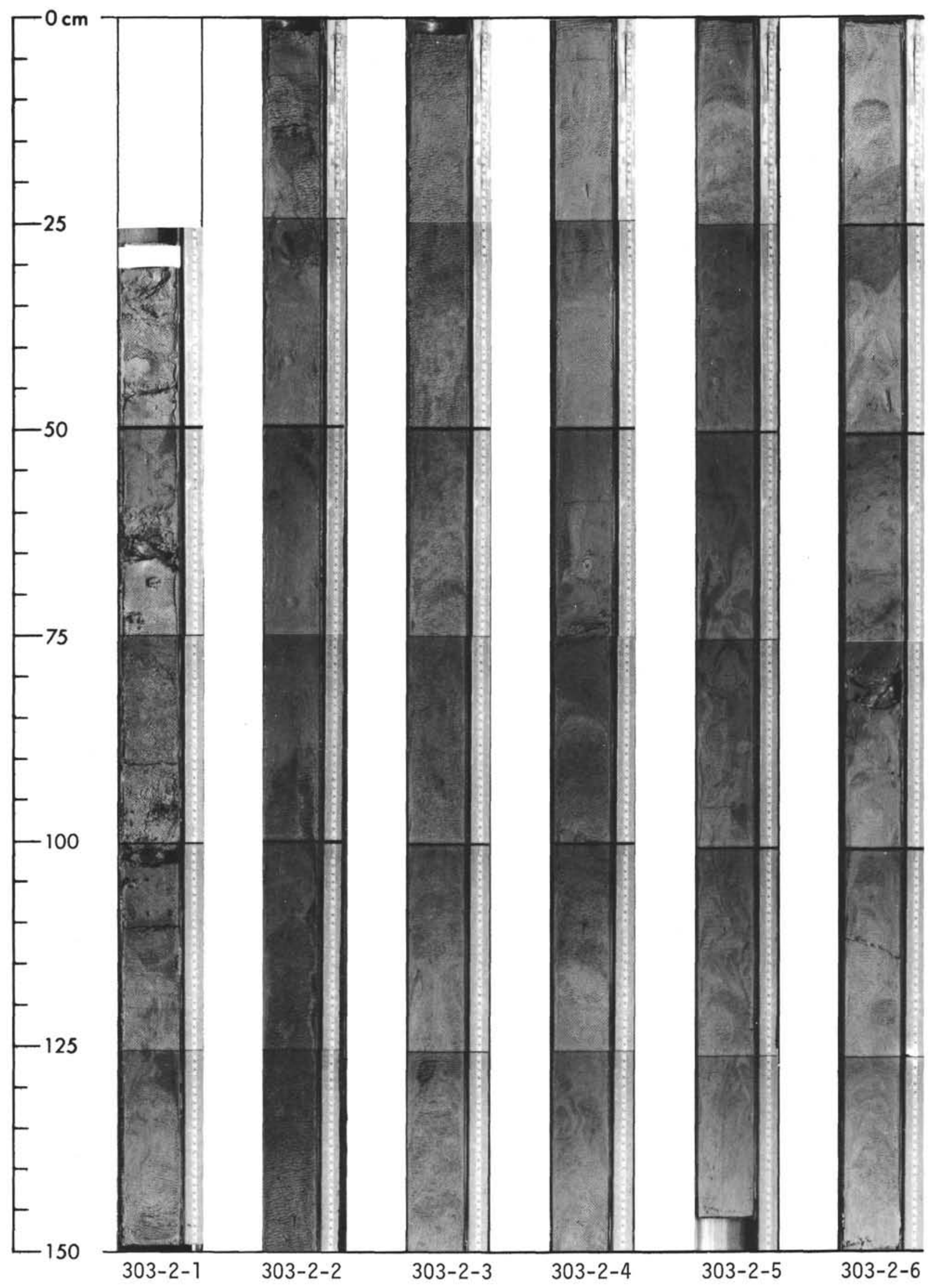


SITE 303

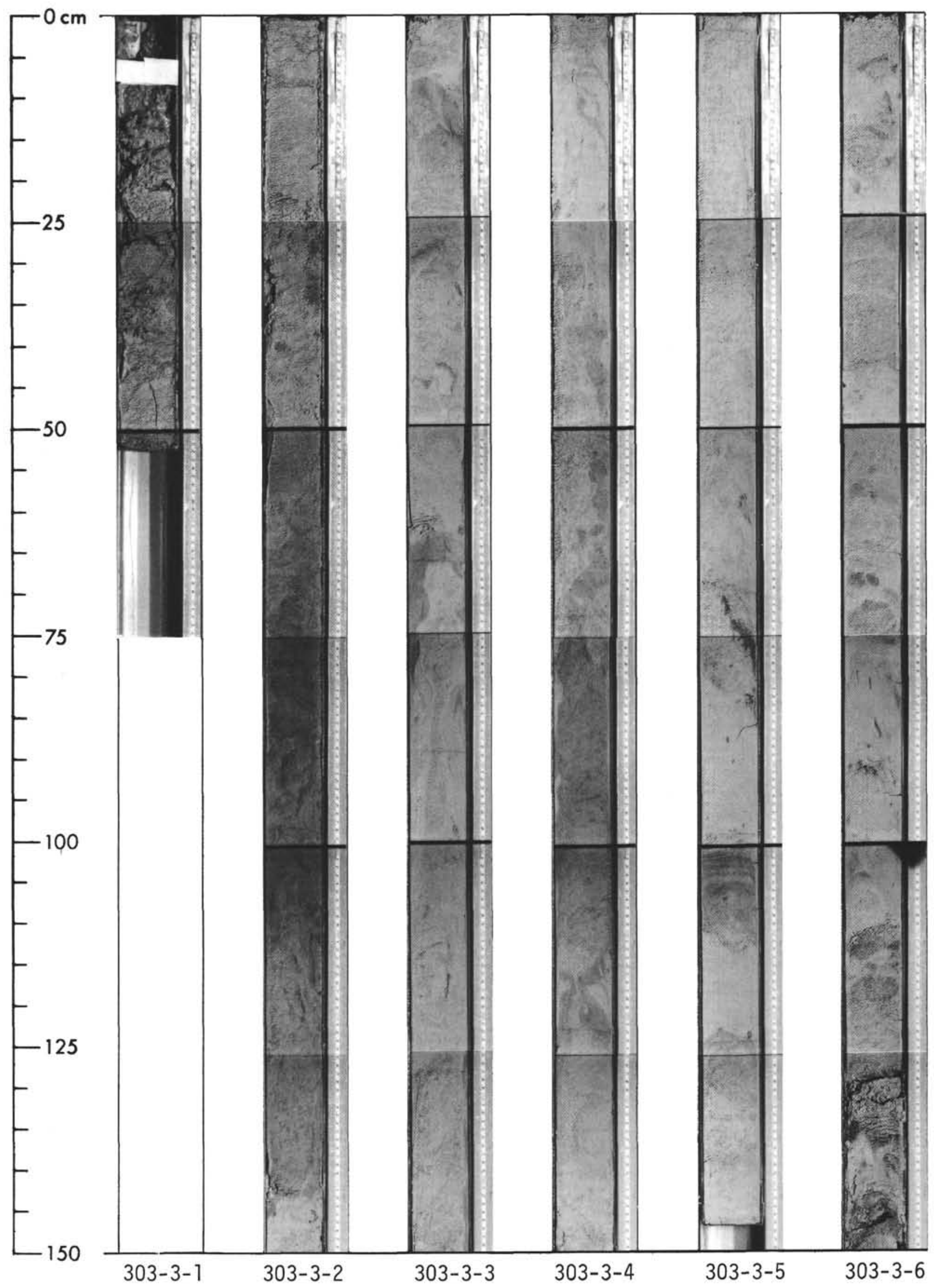




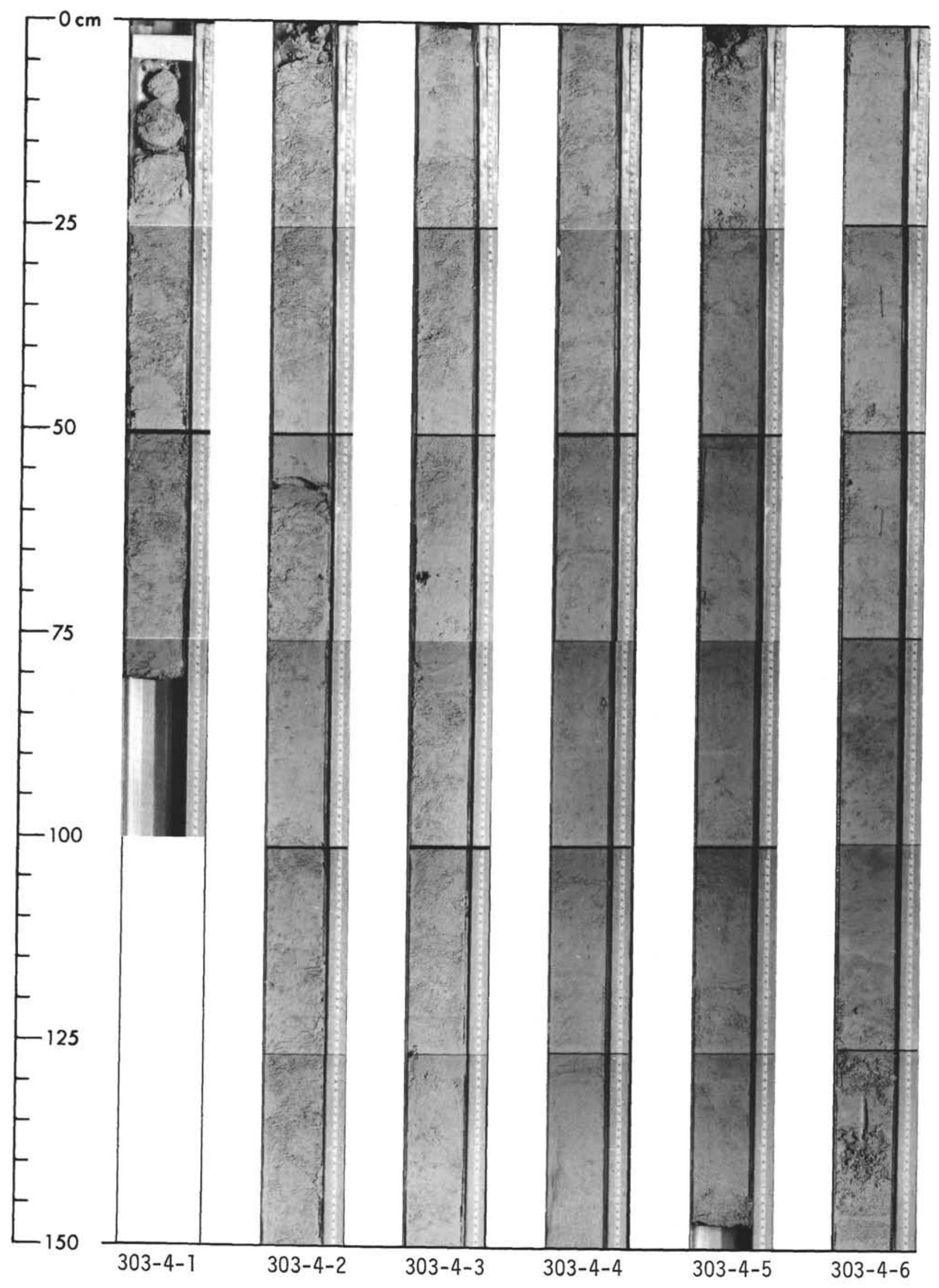




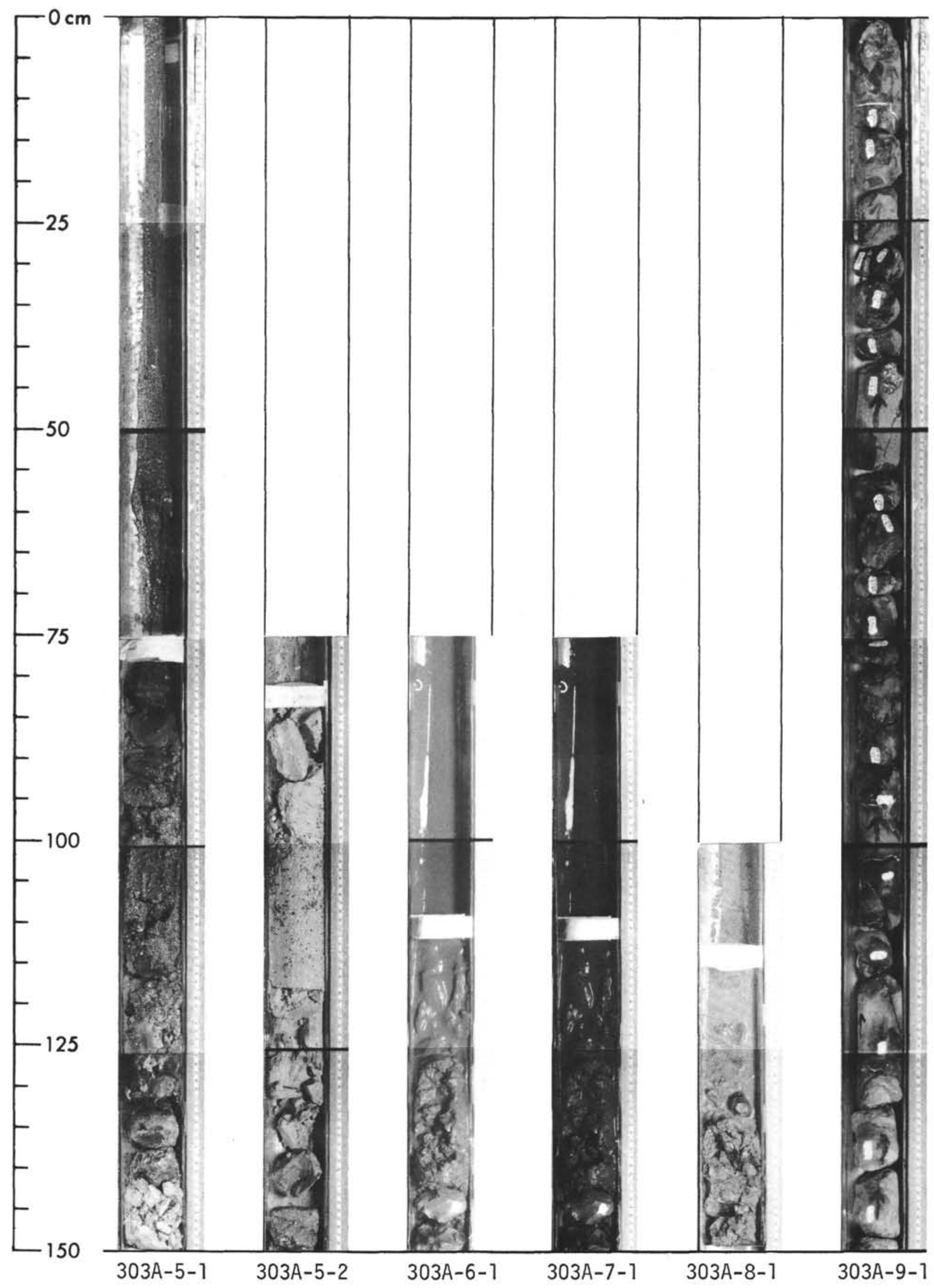




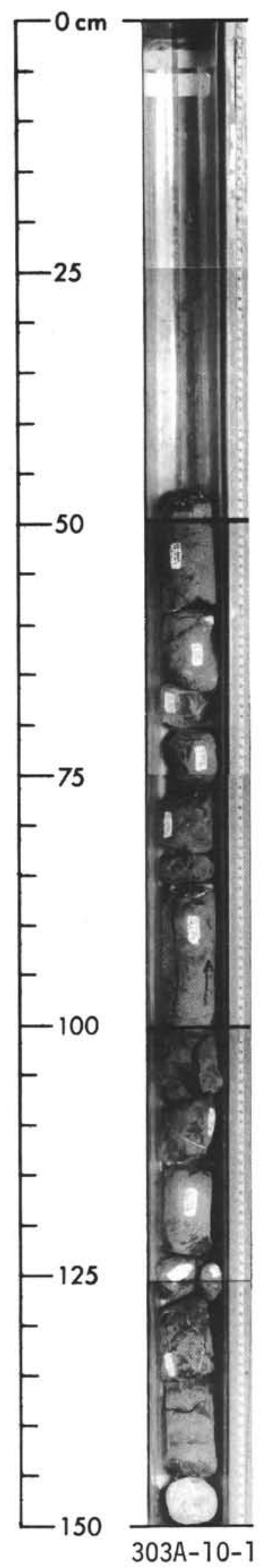

